Article

\title{
Investigation of the Effect of Hydrogen and Methane on Combustion of Multicomponent Syngas Mixtures using a Constructed Reduced Chemical Kinetics Mechanism
}

\author{
Nearchos Stylianidis, Ulugbek Azimov * and Martin Birkett ( \\ Faculty of Engineering and Environment, Northumbria University, Newcastle upon Tyne NE1 8ST, UK; \\ nearchos.stylianidis@northumbria.ac.uk (N.S.); martin.birkett@northumbria.ac.uk (M.B.) \\ * Correspondence: ulugbek.azimov@northumbria.ac.uk
}

Received: 14 May 2019; Accepted: 20 June 2019; Published: 25 June 2019

check for updates

\begin{abstract}
This study investigated the effects of $\mathrm{H}_{2}$ and $\mathrm{CH}_{4}$ concentrations on the ignition delay time and laminar flame speed during the combustion of $\mathrm{CH}_{4} / \mathrm{H}_{2}$ and multicomponent syngas mixtures using a novel constructed reduced syngas chemical kinetics mechanism. The results were compared with experiments and GRI Mech 3.0 mechanism. It was found that mixture reactivity decreases and increases when higher concentrations of $\mathrm{CH}_{4}$ and $\mathrm{H}_{2}$ were used, respectively. With higher $\mathrm{H}_{2}$ concentration in the mixture, the formation of $\mathrm{OH}$ is faster, leading to higher laminar flame speed and shorter ignition delay time. $\mathrm{CH}_{4}$ and $\mathrm{H}_{2}$ concentrations were calculated at different pressures and equivalence ratios, showing that at high pressures $\mathrm{CH}_{4}$ is consumed slower, and, at different equivalence ratios $\mathrm{CH}_{4}$ reacts at different temperatures. In the presence of $\mathrm{H}_{2}, \mathrm{CH}_{4}$ was consumed faster. In the conducted two-stage sensitivity analysis, the first analysis showed that $\mathrm{H}_{2} / \mathrm{CH}_{4} / \mathrm{CO}$ mixture combustion is driven by $\mathrm{H}_{2}$-based reactions related to the consumption/formation of $\mathrm{OH}$ and $\mathrm{CH}_{4}$ recombination reactions are responsible for $\mathrm{CH}_{4}$ oxidation. The second analysis showed that similar $\mathrm{CH}_{4}$-based and $\mathrm{H}_{2}$-based reactions were sensitive in both, methane- and hydrogen-rich $\mathrm{H}_{2} / \mathrm{CH}_{4}$ mixtures. The difference was observed for reactions $\mathrm{CH}_{2} \mathrm{O}+\mathrm{OH}=\mathrm{HCO}+\mathrm{H}_{2} \mathrm{O}$ and $\mathrm{CH}_{4}+\mathrm{HO}_{2}=\mathrm{CH}_{3}+\mathrm{H}_{2} \mathrm{O}_{2}$, which were found to be important for $\mathrm{CH}_{4}$-rich mixtures, while reactions $\mathrm{OH}+\mathrm{HO}_{2}=\mathrm{H}_{2} \mathrm{O}+\mathrm{O}_{2}$ and $\mathrm{HO}_{2}+\mathrm{H}=\mathrm{OH}+\mathrm{OH}$ were found to be important for $\mathrm{H}_{2}$-rich mixtures.
\end{abstract}

Keywords: syngas; chemical kinetics mechanism; reaction sensitivity analysis; laminar flame speed; ignition delay time; digital analysis of reactive systems (DARS)

\section{Introduction}

Increasingly serious environmental problems, due to the harmful exhaust gas emissions produced by the combustion of fossil fuels, along with ongoing fluctuations in crude oil prices, have prompted researchers and engine manufacturers to search for new, environmentally friendly and sustainable fuels [1,2]. Synthesis gas (syngas) is seen as a possible solution as it is produced via the gasification of coal or biomass and produces lower levels of emissions during its combustion in comparison with traditional fossil fuels. Syngas fuels consist of different components such as $\mathrm{H}_{2}, \mathrm{CO}, \mathrm{CH}_{4}, \mathrm{CO}_{2}$ and $\mathrm{H}_{2} \mathrm{O}$. The concentration of each component in the syngas is strongly depended on the type of feedstock and the gasification procedure that is used for its production [3].

For example, the hydrogen concentration in a syngas mixture can vary from $25 \%$ to $80 \%$ depending on the gasification process and the feedstock type used [4]. This variation of the concentration of the different gases in the syngas has a direct effect on important combustion characteristics such as the laminar flame speed, the ignition delay time and the exhaust gas emissions and in general 
on the combustion stability. This has posed a great challenge to engine manufacturers in the sense that combustion chambers must be able to support the combustion of fuels with high compositional variations [5].

During the recent years, the combustion of syngas fuels has been of great interest, mostly due to the chemical and thermal characteristic of $\mathrm{CH}_{4}$ and $\mathrm{H}_{2}$ [6]. In general, mixtures with a high concentration of methane, for example natural gas, produce lower emissions than diesel and petrol during their combustion. However, natural gas is not a sustainable energy source and it currently has a long-term demand $[6,7]$. Both of these factors have intensified the research on finding a sustainable and renewable resource that will be able to replace natural gas or high methane mixtures. Syngas mixtures are characterized as potential replacements of natural gas but unlike natural gas, have not been given much consideration and only a few experimental and numerical studies can be found investigating the effects of individual syngas components, such as $\mathrm{CH}_{4}$ and $\mathrm{H}_{2}$, on their combustion characteristics. Ilbas et al. [8] experimentally analysed the laminar burning velocities of hydrogen-air and hydrogen-methane-air mixtures at various equivalence ratios (0.8-3.2). The authors showed that the burning velocity as well as the flammability limits increased significantly by increasing the hydrogen concentration in the hydrogen-methane mixtures. Moreover, the authors suggested that mixtures of $70 \%$ methane and $30 \%$ hydrogen could be a possible solution and can be used as an alternative fuel for different existing combustion plants.

Mathieu et al. [9] investigated experimentally the ignition of fuel blends representative of a syngas produced from biomass $\left(0.09 \% \mathrm{~mol} \mathrm{CH}_{4} / 0.296 \% \mathrm{~mol} \mathrm{CO} / 0.157 \% \mathrm{~mol} \mathrm{CO}_{2} / 0.3 \% \mathrm{~mol} \mathrm{H}_{2} / 0.2 \% \mathrm{~mol}\right.$ $\mathrm{H}_{2} \mathrm{O} / 0.95 \% \mathrm{~mol} \mathrm{O}_{2} / 98 \% \mathrm{~mol} \mathrm{AR}$ ). The authors showed that the higher concentration of $\mathrm{CO}$ does not affect the combustion process, while the higher concentration of $\mathrm{CH}_{4}$ reduces the reactivity of the mixture and increases the ignition delay time. They concluded that simple $\mathrm{H}_{2} / \mathrm{CO}$ mixtures are not fully adequate to represent real syngas fuels, since concentration of $\mathrm{CH}_{4}$ has a significant effect on the thermochemical properties of the mixtures and affects the fuel oxidation, the ignition of the fuel and the general combustion process. In another research, Watson et al. [9], performed experimental studies comparing the combustion characteristics and the emissions of multicomponent syngas mixtures, which consisted of $\mathrm{CH}_{4} / \mathrm{CO}_{2} / \mathrm{CO} / \mathrm{H}_{2}$ and pure methane. The authors showed that for lean mixtures (equivalence ratios lower than 1.0), multicomponent syngas fuels produced lower NOx emissions than fuels containing only methane. They made the statement that fuels with high hydrogen content (and relatively low methane content) were more appropriate for lean burn applications because of the excess air that will keep the temperatures at moderated levels and reduce the produced NOx emissions [10-12]. Gersen et al. [13] conducted an experimental study for the investigation of $\mathrm{H}_{2} / \mathrm{CO} / \mathrm{CH}_{4}$ syngas combustion at pressures of 20 to 80 bar, equivalence ratios 0.5 and 1.0 and temperatures between $900-1100 \mathrm{~K}$. The authors investigated the effect of the syngas components on the ignition delay time by varying their concentrations. Their results were identical with the results obtained by Mathieu et al. [9]. They found that $\mathrm{CO}$ has a very small effect on the ignition delay time but increased concentration of $\mathrm{CH}_{4}$ reduced the reactivity of the mixture and increased the ignition delay time. They showed that by increasing $\mathrm{H}_{2}$ concentration, ignition delay time was reduced and the combustion intensity increased.

Pio et al. [14], performed an investigation of the laminar burning velocity of different mixtures of hydrogen and methane at low temperatures. The authors compared numerical results obtained by using detailed chemical kinetics mechanisms with experimental data available in the literature. According to the authors, increasing the concentration of hydrogen affects the chemical kinetics and more specifically the activation energy. They showed that the combustion regime dominated by methane for mixtures containing hydrogen content $>60 \%$ is correlated with the limitations presented during hydrogen formation when hydrogen is used as intermediate species in the decomposition chemical path of methane. Furthermore, the authors performed a sensitivity analysis study and they showed that the reaction paths responsible for the production of important species such as $\mathrm{H}$, are affected by the initial conditions and more specifically the low temperatures. 
Recently, Salzano et al. [15] investigated the effect of hydrogen concentration on the premixed flame structure of methane/hydrogen/air mixture at various equivalence ratios and fuel compositions using experimental and numerical results. The authors concluded that the reaction zone thickness of methane/air mixtures was reduced drastically when hydrogen was added at $298 \mathrm{~K}$. In conducted sensitivity study, the authors showed that the addition of hydrogen resulted in higher sensitivity coefficient for reaction $\mathrm{H}+\mathrm{O}_{2}=\mathrm{O}+\mathrm{OH}$, while for pure mixtures under similar conditions, a smaller sensitivity coefficient was observed. This indicates that kinetics paths and the interactions between species play a major role in the combustion process. Finally, the authors made a statement that increasing the amount of carbon atoms in the fuel significantly reduces hydrogen concentration.

Different experimental studies are available in the literature regarding the effects of $\mathrm{H}_{2}$ and $\mathrm{CH}_{4}$ on syngas combustion [16-18] but there is still a need for more detailed analysis of the syngas combustion chemistry. Analysis of the combustion chemistry and investigation of the important reactions that are affected, not only by the concentration of methane and hydrogen but also by the temperature variations, is critical for the identification and the analysis of the factors that affect syngas combustion characteristics and are responsible for combustion instabilities.

Therefore, in this paper, a numerical investigation of the effects of methane and hydrogen on the combustion of multicomponent syngas mixtures has been performed. First, the effects of methane and hydrogen concertation on laminar flame speed and ignition delay time have been investigated. $\mathrm{CH}_{4}$ and $\mathrm{H}_{2}$ concentration profiles during the combustion of different multicomponent mixtures have been calculated at different initial conditions (pressures and equivalence ratios). Numerical results obtained using a reduced syngas chemical kinetics mechanism developed earlier [19] and the detailed GRI Mech. 3.0 [20] are compared against experimental results available in the literature. The reduced syngas mechanism [19] consists of 31 reactions and includes $\mathrm{H}_{2} / \mathrm{CO}$ and $\mathrm{CH}_{4}$ chemical pathways. Then, a detailed chemical analysis has been performed using the reduced syngas mechanism for the identification of the important reactions that have been triggered due to the changes in the mixture composition, which are responsible for decreasing/increasing the reactivity of the mixture.

The difference of this study from the study in Reference [19] is that the aim of the study in Reference [19] was the development of a reduced mechanism that was used in 0D, 1D and 3D analysis of multicomponent syngas combustion in a micro-pilot ignited dual fuel engine. In this paper, the mechanism proposed in Reference [19] was used for a different type of analysis as we focused specifically on the investigation of the effects of $\mathrm{CH}_{4}$ and $\mathrm{H}_{2}$ concentration on ignition delay time and laminar flame speed and the analysis of the combustion chemistry. In contrast to the other published studies, this paper has analysed a two-stage chemical kinetics with the specific focus on, the first, methane oxidation and the second, the comparison of the chemical interactions during the combustion of methane-rich $\mathrm{H}_{2} / \mathrm{CH}_{4}$ and hydrogen-rich $\mathrm{H}_{2} / \mathrm{CH}_{4}$ mixtures.

\section{Chemical Kinetics Mechanism}

During this study, a CFD compatible, reduced syngas chemical kinetics mechanism that was developed in a previous research [19] for the simulation of dual-fuel engine combustion at various engine conditions was used, see Table 1. For the mechanism development, the reduced mechanism proposed by Azimov et al. [21] was used as a reference point and was then re-developed and updated. During the development procedure, a chemical detailed analysis was conducted for the investigation of important hydrogen, methane and carbon based reactions that were found significantly affect the accuracy of the mechanism and the accurate simulation of the combustion process. Therefore, such reactions have been incorporated into the reduced mechanism and their rate constants have been updated. Then the reduced mechanism was tested against experimental and numerical results obtained from the literature in terms of in-cylinder pressure, ROHR, ignition delay time and laminar flame speed for various syngas mixtures. Full details about the development, validation and testing procedures that were followed for the reduce mechanism development can be found in Reference [19]. The mechanism 
consists of 31 reactions and includes important hydrogen-based, methane-based and carbon-based reactions. It can be used for the simulation of various multicomponent syngas mixtures.

Table 1. Reduced chemical kinetics mechanism [19] used in this study.

\begin{tabular}{|c|c|c|c|c|c|}
\hline & Reactions & A (cal-cm-sec-K) & $\mathbf{n}$ & E (cal/mol) & Ref. \\
\hline $\mathrm{R} 1$ & $\mathrm{CH}_{4}+\mathrm{O}_{2}=\mathrm{CH}_{3}+\mathrm{HO}_{2}$ & $3.98 \times 10^{13}$ & 0.0 & $56,855.5$ & [22] \\
\hline $\mathrm{R} 2$ & $\mathrm{CH}_{4}+\mathrm{HO}_{2}=\mathrm{CH}_{3}+\mathrm{H}_{2} \mathrm{O}_{2}$ & $0.964 \times 10^{11}$ & 0.0 & $24,629.4$ & [22] \\
\hline R3 & $\mathrm{CH}_{4}+\mathrm{OH}=\mathrm{CH}_{3}+\mathrm{H}_{2} \mathrm{O}$ & $1.60 \times 10^{7}$ & 1.83 & 2771.1 & [23] \\
\hline R4 & $\mathrm{CH}_{3}+\mathrm{O}_{2}=\mathrm{CH}_{2} \mathrm{O}+\mathrm{OH}$ & $3.30 \times 10^{11}$ & 0.0 & 8934.4 & [22] \\
\hline R5 & $\mathrm{CH}_{2} \mathrm{O}+\mathrm{OH}=\mathrm{HCO}+\mathrm{H}_{2} \mathrm{O}$ & $3.90 \times 10^{10}$ & 0.0 & 406.1 & [22] \\
\hline R6 & $\mathrm{CO}+\mathrm{O}(+\mathrm{M})=\mathrm{CO}_{2}(+\mathrm{M})$ & $9.04 \times 10^{12}$ & 0.89 & 3800.0 & [23] \\
\hline \multicolumn{6}{|c|}{$\begin{array}{cccc}\mathrm{LOW} / & 0.2070 \times 10^{27} & -3.340 & 7610.0 \\
/ \mathrm{M} / \mathrm{H}_{2} \mathrm{O} / 12.00 / \mathrm{H}_{2} / 2.00 / \mathrm{CO} / 1.50 / \mathrm{CO}_{2} / 2.00 / \mathrm{AR} / 0.50 /\end{array}$} \\
\hline R7 & $\mathrm{CO}+\mathrm{OH}=\mathrm{CO}_{2}+\mathrm{H}$ & $0.9600 \times 10^{12}$ & 0.14 & 7352.0 & [23] \\
\hline R8 & $\mathrm{CO}+\mathrm{OH}=\mathrm{CO}_{2}+\mathrm{H}$ & $0.7320 \times 10^{11}$ & -1.00 & -16.0 & [23] \\
\hline R9 & $\mathrm{CO}+\mathrm{HO}_{2}=\mathrm{CO}_{2}+\mathrm{OH}$ & $0.1200 \times 10^{18}$ & 0.00 & $17,000.0$ & [23] \\
\hline $\mathrm{R} 10$ & $\mathrm{CO}+\mathrm{H}_{2} \mathrm{O}=\mathrm{CO}_{2}+\mathrm{H}_{2}$ & $0.2000 \times 10^{9}$ & 0.00 & $38,000.0$ & [23] \\
\hline R11 & $\mathrm{HCO}(+\mathrm{M})=\mathrm{CO}+\mathrm{H}(+\mathrm{M})$ & $0.3000 \times 10^{14}$ & 0.03 & $23,000.0$ & [23] \\
\hline \multicolumn{6}{|c|}{$/ \mathrm{M} / \mathrm{H}_{2} \mathrm{O} / 5.00 / \mathrm{CO}_{2} / 3.00 / \mathrm{H}_{2} / 1.90 / \mathrm{CO} / 1.90 /$} \\
\hline R12 & $\mathrm{HCO}+\mathrm{O}=\mathrm{CO}_{2}+\mathrm{H}$ & $0.3000 \times 10^{14}$ & 0.00 & 0.0 & [23] \\
\hline R13 & $\mathrm{HCO}+\mathrm{H}=\mathrm{H}_{2}+\mathrm{CO}$ & $0.1000 \times 10^{13}$ & 0.00 & 0.0 & [23] \\
\hline R14 & $\mathrm{HCO}+\mathrm{OH}=\mathrm{H}_{2} \mathrm{O}+\mathrm{CO}$ & $0.5000 \times 10^{14}$ & 0.00 & 0.0 & [23] \\
\hline R15 & $\mathrm{HCO}+\mathrm{HO}_{2}=\mathrm{H}_{2} \mathrm{O}_{2}+\mathrm{CO}$ & $0.4000 \times 10^{12}$ & 0.00 & 0.0 & [23] \\
\hline R16 & $\mathrm{HCO}+\mathrm{HO}_{2}=>\mathrm{H}+\mathrm{OH}+\mathrm{CO}_{2}$ & $0.3000 \times 10^{14}$ & 0.00 & 0.0 & [23] \\
\hline R17 & $\mathrm{O}_{2}+\mathrm{CO}=\mathrm{CO}_{2}+\mathrm{O}$ & $0.2530 \times 10^{10}$ & 0.00 & 0.0 & [23] \\
\hline R18 & $\mathrm{O}_{2}+\mathrm{HCO}=\mathrm{HO}_{2}+\mathrm{CO}$ & $0.1000 \times 10^{15}$ & 0.00 & $47,700.0$ & [23] \\
\hline R19 & $\mathrm{OH}+\mathrm{OH}(+\mathrm{M})=\mathrm{H}_{2} \mathrm{O}_{2}(+\mathrm{M})$ & $0.7400 \times 10^{14}$ & -0.370 & 0.0 & [23] \\
\hline \multicolumn{6}{|c|}{$/ \mathrm{M} / \mathrm{H}_{2} / 2.00 / \mathrm{H}_{2} \mathrm{O} / 6.00 / \mathrm{CO} / 1.50 / \mathrm{CO}_{2} / 2.00 / \mathrm{AR} / 0.70 /$} \\
\hline $\mathrm{R} 20$ & $\mathrm{H}+\mathrm{O}_{2}=\mathrm{OH}+\mathrm{O}$ & $3.52 \times 10^{16}$ & -0.7 & $17,061.4$ & [24] \\
\hline $\mathrm{R} 21$ & $\mathrm{H}_{2}+\mathrm{O}=\mathrm{OH}+\mathrm{H}$ & $5.06 \times 10^{4}$ & 2.67 & 6287.6 & [25] \\
\hline $\mathrm{R} 22$ & $\mathrm{H}_{2}+\mathrm{OH}=\mathrm{H}_{2} \mathrm{O}+\mathrm{H}$ & $1.17 \times 10^{9}$ & 1.3 & 0.0 & [26] \\
\hline $\mathrm{R} 23$ & $\mathrm{H}+\mathrm{O}_{2}(+\mathrm{M})=>\mathrm{HO}_{2}+(\mathrm{M})$ & $4.6 \times 10^{12}$ & 0.4 & 0.0 & {$[27]$} \\
\hline \multicolumn{6}{|c|}{ 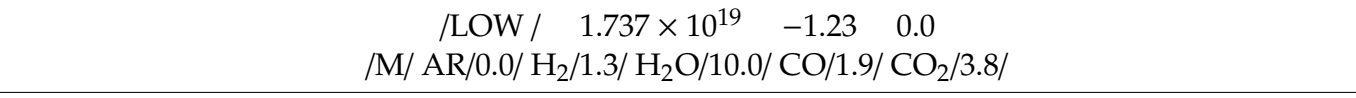 } \\
\hline $\mathrm{R} 24$ & $\mathrm{H}+\mathrm{H}+(\mathrm{M})=>\mathrm{H}_{2}+(\mathrm{M})$ & $1.30 \times 10^{18}$ & -1 & 0.0 & [25] \\
\hline \multicolumn{6}{|c|}{$/ \mathrm{M} / \mathrm{H}_{2} / 2.5 / \mathrm{H}_{2} \mathrm{O} / 12.0 / \mathrm{CO} / 1.9 / \mathrm{CO}_{2} / 3.8 / \mathrm{AR} / 0.5 /$} \\
\hline $\mathrm{R} 25$ & $\mathrm{H}+\mathrm{OH}(+\mathrm{M})=>\mathrm{H}_{2} \mathrm{O}(+\mathrm{M})$ & $4.00 \times 10^{22}$ & -2 & 0.0 & [25] \\
\hline \multicolumn{6}{|c|}{$/ \mathrm{M} / \mathrm{H}_{2} / 2.5 / \mathrm{H}_{2} \mathrm{O} / 12.0 / \mathrm{CO} / 1.9 / \mathrm{CO}_{2} / 3.8 / \mathrm{AR} / 0.38 /$} \\
\hline $\mathrm{R} 26$ & $\mathrm{HO}_{2}+\mathrm{H}=>\mathrm{OH}+\mathrm{OH}$ & $7.08 \times 10^{13}$ & 0.0 & 298.8 & [28] \\
\hline $\mathrm{R} 27$ & $\mathrm{HO}_{2}+\mathrm{H}=\mathrm{H}_{2}+\mathrm{O}_{2}$ & $1.66 \times 10^{13}$ & 0.0 & 821.8 & [27] \\
\hline R28a & $\mathrm{HO}_{2}+\mathrm{OH}=\mathrm{H}_{2} \mathrm{O}+\mathrm{O}_{2}$ & $2.89 \times 10^{13}$ & 0.0 & -500 & [29] \\
\hline $\mathrm{R} 28 \mathrm{~b}$ & $\mathrm{HO}_{2}+\mathrm{OH}=\mathrm{H}_{2} \mathrm{O}+\mathrm{O}_{2}$ & $2.456 \times 10^{13}$ & 0.0 & -497 & [27] \\
\hline $\mathrm{R} 29$ & $\mathrm{HO}_{2}+\mathrm{HO}_{2}=\mathrm{H}_{2} \mathrm{O}_{2}+\mathrm{O}_{2}$ & $1.300 \times 10^{11}$ & 0.00 & $-1.630 \times 10^{3}$ & [27] \\
\hline $\mathrm{R} 30$ & $\mathrm{H}_{2} \mathrm{O}_{2}+\mathrm{H}=\mathrm{H}_{2}+\mathrm{HO}_{2}$ & $7.7 \times 10^{12}$ & 0.0 & 3755 & [29] \\
\hline R31 & $\mathrm{O}+\mathrm{H}_{2} \mathrm{O}=\mathrm{OH}+\mathrm{OH}$ & $2.97 \times 10^{6}$ & 2.02 & $1.340 \times 10^{4}$ & [28] \\
\hline
\end{tabular}

\section{Modelling Approach}

As already highlighted, multicomponent syngas mixtures produced from biomass, include a small amount of $\mathrm{CH}_{4}$ that has a significant effect on the combustion characteristics, such as the laminar 
flame speed and ignition delay time. In order to investigate the effects of $\mathrm{CH}_{4}$ on syngas combustion, a two-stage process was conducted. For the first stage, zero and one-dimensional simulations were performed for testing the reduced mechanism on simulating laminar flame speed and ignition delay times of different $\mathrm{CH}_{4} / \mathrm{H}_{2}$ and $\mathrm{H}_{2} / \mathrm{CO} / \mathrm{CH}_{4}$ mixtures and the investigation of the effects of $\mathrm{CH}_{4}$ and $\mathrm{H}_{2}$ on ignition delay time and laminar flame speed. For the mechanism validation, the numerical results from the reduced mechanism [19] were compared against numerical results obtained using the detailed GRI Mech. 3.0 [20] and experimental measurements obtained from the literature. The effects of temperature, pressure and equivalence ratio on methane and hydrogen oxidation were investigated by calculating the methane and hydrogen concentrations profiles during the combustion of different $\mathrm{H}_{2} / \mathrm{CH}_{4}$ mixtures at various initial conditions. The second stage includes two reaction sensitivity analysis. For the first, important reactions affecting $\mathrm{H}_{2} / \mathrm{CO} / \mathrm{CH}_{4}$ syngas combustion at different equivalence ratios were analysed, while for the second, important methane-based and hydrogen-based reactions affecting $\mathrm{CH}_{4}$-rich and $\mathrm{H}_{2}$-rich $\mathrm{H}_{2} / \mathrm{CH}_{4}$ mixtures were compared and discussed.

Zero and one-dimensional simulations as well as sensitivity analysis were performed using Digital Analysis of Reactive systems (DARS) software [30]. DARS has been built with the specific purpose of enabling detailed chemical kinetics analysis of engineering applications, with particular focus on internal combustion engines. It incorporates a suite of reactor models and reaction mechanisms for the detailed investigation of combustion chemistry.

\subsection{Ignition Delay Time}

For the simulation of the ignition delay times in conditions relevant to rapid compression machine (RCM), the constant volume reactor implemented in DARS was used by assuming adiabatic conditions [31]. The ignition delay times were calculated based on the slope of the in-cylinder pressure tracers and the maximum slope of the $\mathrm{OH}$ concentration. Many authors have studied the relationship between the formation of $\mathrm{OH}$ radicals and the in-cylinder temperature changes [32,33]. They showed that the concentration of $\mathrm{OH}$ increases with temperature and therefore can be used as an indicator of the combustion initiation [32-34].

\subsection{Laminar Flame Speed}

Laminar flame speed simulations have been performed using the one-dimensional premixed laminar flame propagating module incorporated in DARS [35]. According to previous studies, thermal diffusion and radiation factors have a significant effect on the accuracy of the simulations [22]. Keromnes et al. [27] showed that, for stoichiometric mixtures, the calculated laminar flame speed increased by $8 \%$ if the thermal diffusion and radiation factors are excluded from the simulations. Therefore, for better accuracy, it was decided to include both of these factors in all of the simulations. The convergent solution was adjusted to be obtained by using 400 grid points.

\subsection{Species Concentration Profiles}

The concentration profiles of methane and hydrogen during the combustion of different $\mathrm{H}_{2} / \mathrm{CH}_{4}$ fuels were calculated using the constant volume module available in DARS. The mole fractions of hydrogen and methane were calculated at different temperatures, pressures and equivalence ratios. The initial and boundary conditions used during the simulations were taken directly from the experimental investigations, allowing a direct comparison of the simulated results with the experimental measurements.

\subsection{Sensitivity Analysis}

Sensitivity analysis is a well -established method for the detailed analysis of complex chemical kinetic systems, investigation of the most sensitive reactions and species and the reduction of detailed mechanisms [36-38]. Each specie is rated based on its own contribution to the formation and the consumption of other important species [32]. Therefore, it can be said that sensitivities are transported 
through the chemical kinetic mechanism. For each individual species, sensitivity is used to describe how sensitive a specie is towards a chosen parameter $A$ and is calculated by the summary of the reaction sensitivities $(p)$ in which the species will take part [36,37]:

$$
S_{A, i}^{p}=\sum_{k=1}^{N_{r}} \frac{d \Psi_{A}}{d r_{k}} \cdot \frac{u^{\prime}{ }_{i, k}}{c_{i}} \cdot r_{k}
$$

Here $S_{A, i}^{p}$ is the summary of the reaction sensitivities and contains the information on how sensitive an arbitrary parameter, $A$, in the vector of unknowns, $d \Psi_{A}$, is to species $i$. Where, $k$ is the reaction rate, $w$ is the production rate, $r_{k}$ is the internal energy of reaction $\mathrm{k}$ and $c_{i}$ is the concentration of species $i$. It is important to mention here that the arbitrary parameter, $A$, could be an important combustion parameter such as the pressure or temperature or the flow rate of certain species [37].

\section{Fuel Mixtures Used in This Study}

Experimental results for various $\mathrm{CH}_{4} / \mathrm{H}_{2}$ as well as $\mathrm{H}_{2} / \mathrm{CO} / \mathrm{CH}_{4}$ syngas mixtures were collected from the literature and used for mechanism testing. The investigation of the effects of $\mathrm{CH}_{4}$ and $\mathrm{H}_{2}$ concentration on laminar flame speed and ignition delay time, the calculation of $\mathrm{CH}_{4}$ and $\mathrm{H}_{2}$ concentration profile time and finally, for reaction sensitivity analysis. All of the syngas mixtures used during this study are presented in Table 2 with the range of equivalence ratios, initial pressures and temperatures.

Table 2. Syngas blends used during this study.

\begin{tabular}{|c|c|c|c|c|c|c|c|c|}
\hline No. & Fuel Mixture & Model & $\begin{array}{c}\text { Initial } \\
\text { Pressure } \\
\text { (bar) }\end{array}$ & $\begin{array}{c}\text { Initial } \\
\text { Temperature } \\
\text { (K) }\end{array}$ & \multicolumn{2}{|c|}{$\begin{array}{l}\text { Composition in Volume } \\
\text { Fractions }(\%)\end{array}$} & Eq. Ratio & Ref. \\
\hline Fuel 1 & $\mathrm{CH}_{4} / \mathrm{H}_{2}$ & Ignition delay time & $5,10,20$ & $1050-1820$ & $\begin{array}{l}\text { Type1 } \\
\text { Type } 2 \\
\text { Type3 } \\
\text { Type4 }\end{array}$ & $\begin{array}{l}80 / 20 \\
60 / 40 \\
40 / 60 \\
20 / 80\end{array}$ & 0.5 & [39] \\
\hline Fuel 2 & $\mathrm{CH}_{4} / \mathrm{H}_{2}$ & Laminar Flame speed & 1 & 298 & $\begin{array}{l}\text { Type } 1 \\
\text { Type } 2 \\
\text { Type } 3\end{array}$ & $\begin{array}{l}80 / 20 \\
50 / 50 \\
10 / 90\end{array}$ & $0.5-1.3$ & [40] \\
\hline Fuel 3 & $\mathrm{CH}_{4} / \mathrm{H}_{2}$ & Laminar Flame Speed & 1 & 300 & $\begin{array}{l}\text { Type } 1 \\
\text { Type } 2 \\
\text { Type } 3\end{array}$ & $\begin{array}{l}100 / 0 \\
85 / 15 \\
70 / 30\end{array}$ & $0.65-1.1$ & {$[41,42]$} \\
\hline Fuel 4 & $\mathrm{CH}_{4} / \mathrm{H}_{2} / \mathrm{CO}$ & Laminar Flame speed & 1 & 295 & $\begin{array}{l}\text { Type1 } \\
\text { Type } 2\end{array}$ & $\begin{array}{l}20 / 40 / 40 \\
40 / 30 / 30\end{array}$ & $0.75-1.3$ & [43] \\
\hline Fuel 5 & $\mathrm{CH}_{4} / \mathrm{H}_{2}$ & $\begin{array}{l}\text { Species concentration } \\
\text { profiles }\end{array}$ & $\begin{array}{c}1,10 \\
1\end{array}$ & $\begin{array}{l}900-1450 \\
950-1125\end{array}$ & $\begin{array}{l}\text { Type } 1 \\
\text { Type } 2\end{array}$ & $\begin{array}{l}100 / 0 \\
50 / 50\end{array}$ & $\begin{array}{c}0.1,0.6 \text { and } 1.5 \\
0.1 \text { and } 0.6\end{array}$ & [44] \\
\hline Fuel 6 & $\begin{array}{c}\mathrm{CH}_{4} / \mathrm{H}_{2} / \mathrm{H}_{2} \mathrm{O} / \\
\mathrm{CO} / \mathrm{CO}_{2} / \mathrm{N}_{2}\end{array}$ & $\begin{array}{l}\text { Species concentration } \\
\text { profiles }\end{array}$ & 1.3 & 990 & $\begin{array}{l}\text { Type } 1 \\
\text { Type } 2\end{array}$ & $\begin{array}{l}14 / 16 / 25 / 19 / 14 / 12 \\
14 / 32 / 18 / 12 / 12 / 12\end{array}$ & 0.5 & [45] \\
\hline Fuel 7 & $\mathrm{H}_{2} / \mathrm{CO} / \mathrm{CH}_{4}$ & $\begin{array}{l}\text { Reaction sensitivity } \\
\text { analysis }\end{array}$ & 10 & 1125 & & $/ 30 / 40$ & $0.5,1.0$ and 1.5 & [43] \\
\hline Fuel 8 & $\mathrm{CH}_{4} / \mathrm{H}_{2}$ & $\begin{array}{l}\text { Reaction sensitivity } \\
\text { analysis }\end{array}$ & 10 & 1100 & $\begin{array}{l}\text { Type } 1 \\
\text { Type } 2\end{array}$ & $\begin{array}{l}20 / 80 \\
80 / 20\end{array}$ & 0.5 & [40] \\
\hline
\end{tabular}

\section{Results and Discussion}

\subsection{Ignition Delay Time}

\section{$\mathrm{CH}_{4} / \mathrm{H}_{2}$ Fuel Mixture}

The effect of $\mathrm{CH}_{4}$ and $\mathrm{H}_{2}$ concentration on ignition delay time was investigated using the experimental measurements from Zhang et al. [39], Fuel 1, Table 2. The comparisons are presented in the Figure 1 for pressure 5 bar, Figure 2 for pressure 10 bar and Figure 3 for pressure 20 bar. The results show that the reduced mechanism [19] and GRI Mech.3.0 [20] accurately simulate the effect 
of temperature and mixture composition on the ignition delay time compared to the experimental results, especially for high methane mixtures $\left(\mathrm{CH}_{4} / \mathrm{H}_{2} 60 / 40 \%\right.$ and $\left.80 / 20 \%\right)$. However, for high $\mathrm{H}_{2}$ mixtures, GRI Mech. 3.0 [20] is higher at all of the tested temperatures for both mixtures $\left(\mathrm{CH}_{4} / \mathrm{H}_{2}\right.$ $80 / 20 \%$ and $40 / 60 \%$ ). For example, at lower temperatures $(1150 \mathrm{~K})$ the ignition delay time using GRI Mech. 3.0 [20] is $1715 \mu$ s for $\mathrm{H}_{2} 60 \%$ while for the same conditions the experimental ignition delay time is $1300 \mu \mathrm{s}$. Moreover, for $\mathrm{H}_{2} 80 \%$ and temperature $1100 \mathrm{~K}$, the ignition delay time using GRI Mech.3.0 [20] is $1100 \mu$ s while the experimental ignition delay time is $450 \mu$ s. This discrepancy is because GRI Mech. 3.0 was initially constructed for the simulation of natural gas mixtures (methane compositions higher than 50\%).

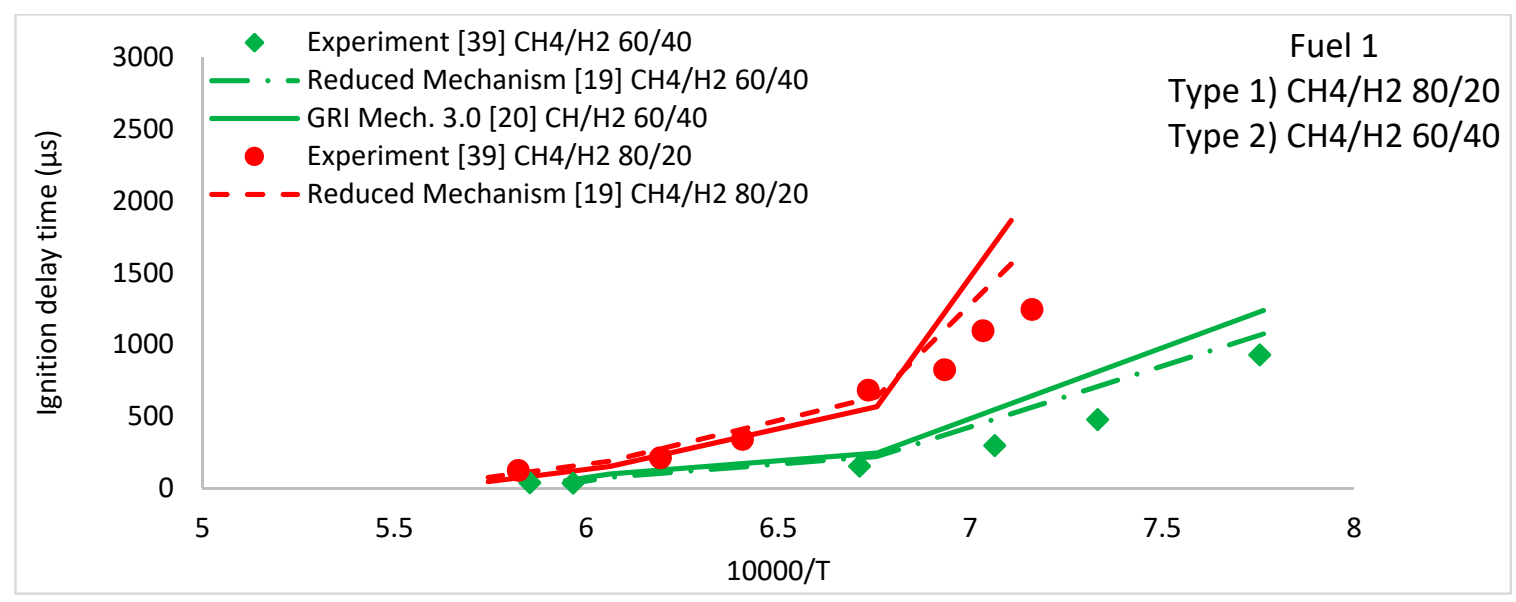

(a)

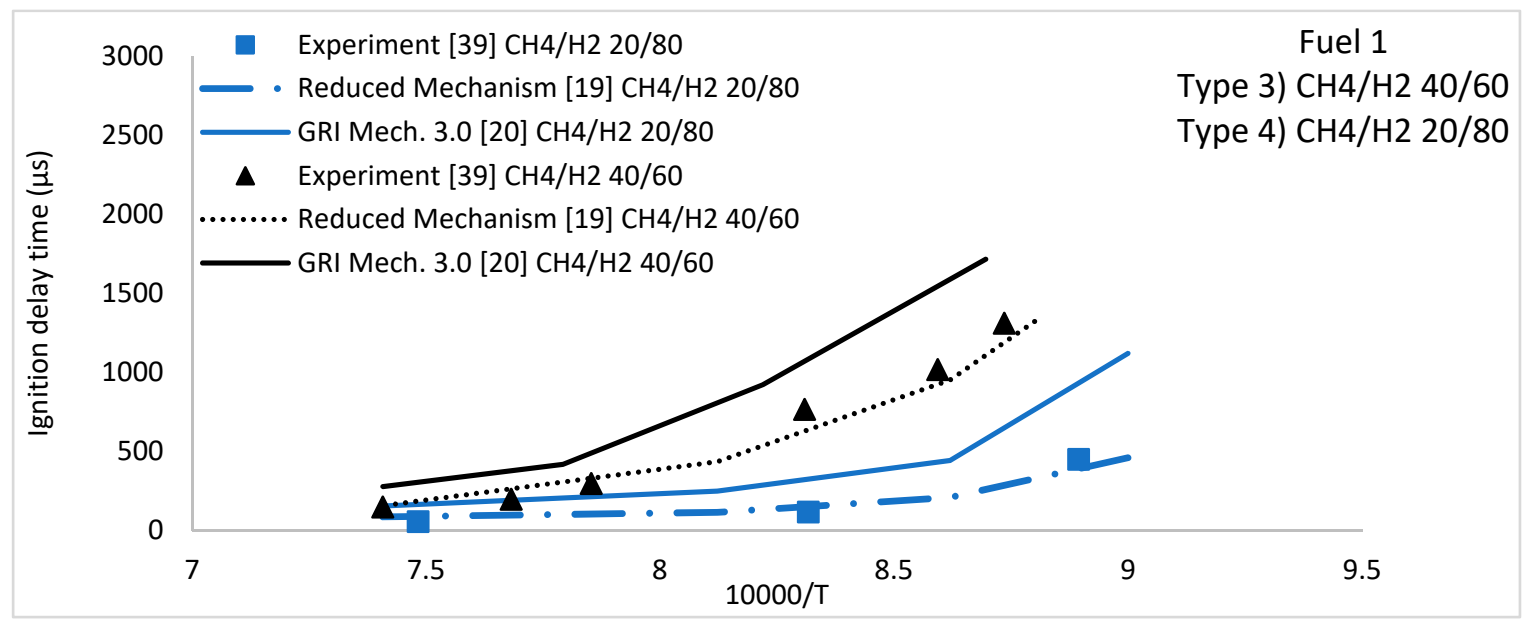

(b)

Figure 1. Comparison of the calculated ignition delay time by using the reduced mechanism [19] and GRI Mech. 3.0 [20] and the experimental measurements from Reference [39] for (a) Fuel 1 Type 1 and Type 2; and (b) Fuel 1 Type 3 and Type 4 at pressure 5 bar and equivalence ratio 0.5. 


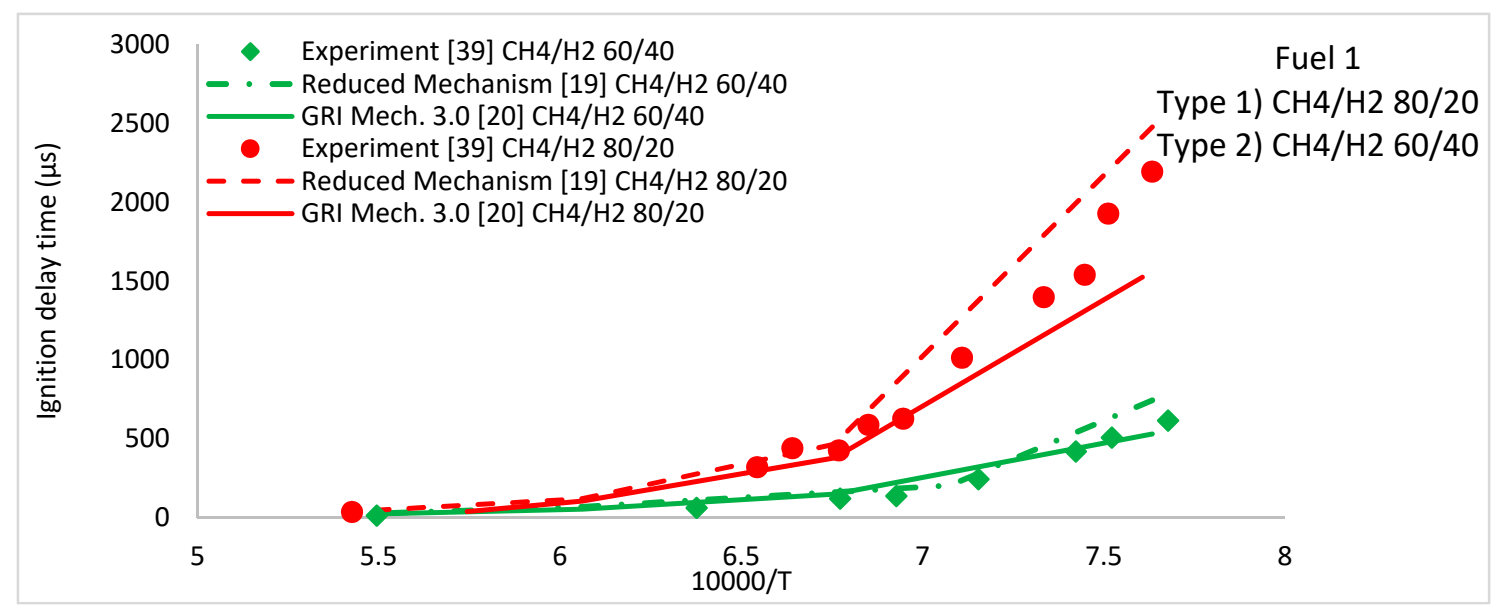

(a)

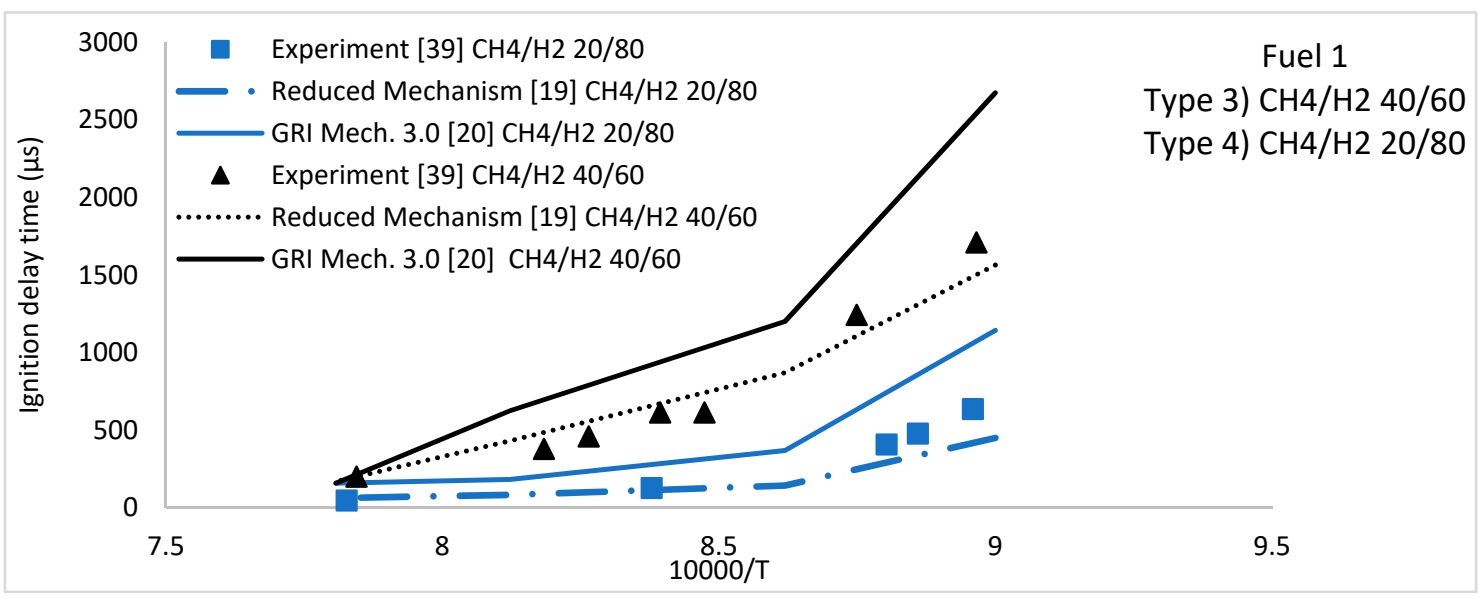

(b)

Figure 2. Comparison of the calculated ignition delay time by using the reduced mechanism [19] and GRI Mech. 3.0 [20] and the experimental measurements from Reference [39] for (a) Fuel 1 Type 1 and Type 2; and (b) Fuel 1 Type 3 and Type 4 at pressure 10 bar and equivalence ratio 0.5.

For all of the conditions tested, a significant decrease of the ignition delay with increase in temperature was observed. This is because the auto-ignition temperature of the fuel mixture is reached faster when the temperature is higher [39]. The effect of $\mathrm{CH}_{4}$ and $\mathrm{H}_{2}$ concentrations on ignition delay time can be seen: the higher the amount of $\mathrm{CH}_{4}$ in the mixture, the longer the ignition delay time, while the higher the amount of $\mathrm{H}_{2}$, the faster the reactivity of the mixture. This phenomenon is more obvious at lower temperatures, in which, the ignition delay time and the reactivity of the mixture are strongly dependent on the mixture composition [40]. For example, at pressure 5 bar (Figure 1), the ignition delay time of $\mathrm{CH}_{4} / \mathrm{H}_{2} 80 / 20 \%$ at $1400 \mathrm{~K}$, is $640 \mu$ s in comparison with the ignition delay time of $\mathrm{CH}_{4} / \mathrm{H}_{2} 20 / 80 \%$ at similar initial conditions (pressure, temperature and equivalence ratio), which is 3 times shorter, $210 \mu$ s. 


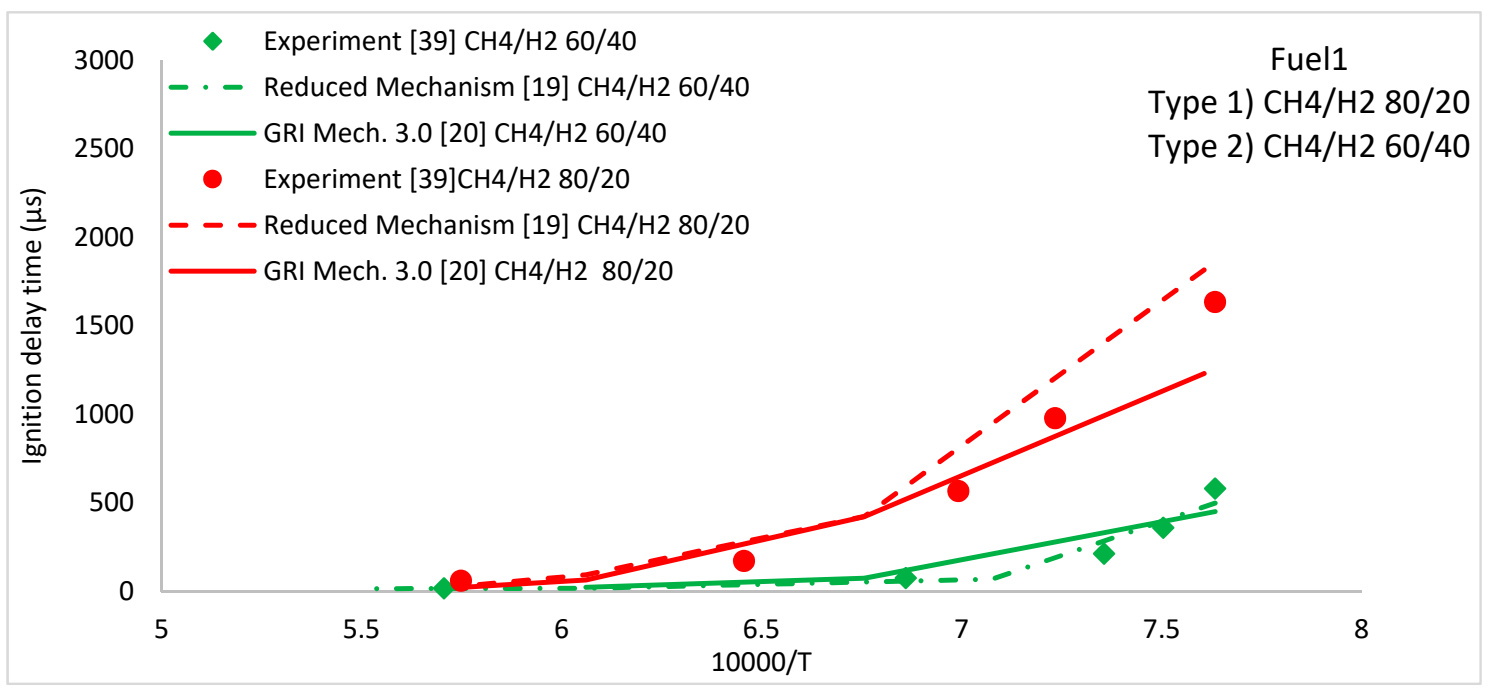

(a)

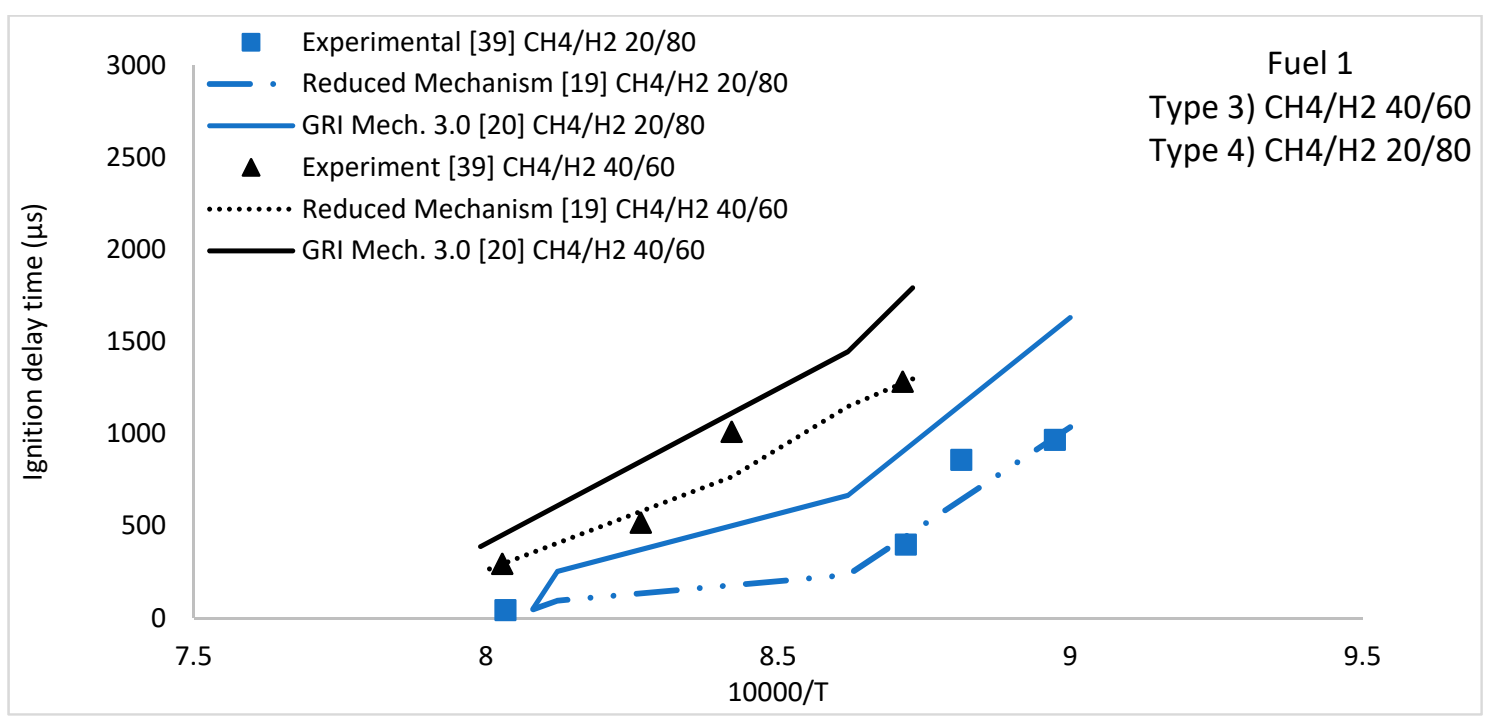

(b)

Figure 3. Comparison of the calculated ignition delay time by using the reduced mechanism [19] and GRI Mech. 3.0 [20] and the experimental measurements from Reference [39] for (a) Fuel 1 Type 1 and Type 2; and (b) Fuel 1 Type 3 and Type 4 at pressure 20 bar and equivalence ratio 0.5.

\subsection{Laminar Flame Speed}

\subsection{1. $\mathrm{H}_{2} / \mathrm{CH}_{4}$ Fuel Mixture}

In terms of laminar flame speed, in order to validate the performance of the reduced mechanism [19] and GRI Mech. 3.0 [20] and investigate the effect of $\mathrm{CH}_{4}$ concentration and equivalence ratio on the mixtures reactivity, the experimental measurements from Donohoe et al. [40], Fuel 2, Table 2, were used. These authors measured the laminar flame speed of different $\mathrm{H}_{2} / \mathrm{CH}_{4}$ mixtures $(20 / 80 \%, 50 / 50 \%$ and $90 / 10 \%$ ) at pressure 1 bar, temperature $298 \mathrm{~K}$ and a range of equivalence ratios of $0.5-1.3$. The results are presented in Figure 4. It can be seen that both mechanisms accurately simulate the experimental results obtained using fuel mixtures with $\mathrm{CH}_{4}$ content $50 \%$ and $80 \%$. However, for $\mathrm{H}_{2} 90 \%$, GRI Mech. 3.0 shows a significant deviation with the experimental results, while the reduced mechanism is close to the experiment. For example, the maximum laminar flame speed reached at equivalence ratio 1.3 using the reduced mechanism is $341 \mathrm{~m} / \mathrm{s}$ while the experimental maximum laminar flame speed at 
the same equivalence ratio is $330 \mathrm{~m} / \mathrm{s}$. On the other hand, by using GRI Mech. 3.0 [20], the maximum laminar flame speed at equivalence ratio 1.3 is $375 \mathrm{~m} / \mathrm{s}$. This is in agreement with the results observed from the ignition delay comparison, in which GRI Mech. 3.0 showed a significant deviation with the experimental results when mixtures with high $\mathrm{H}_{2}$ content were used.

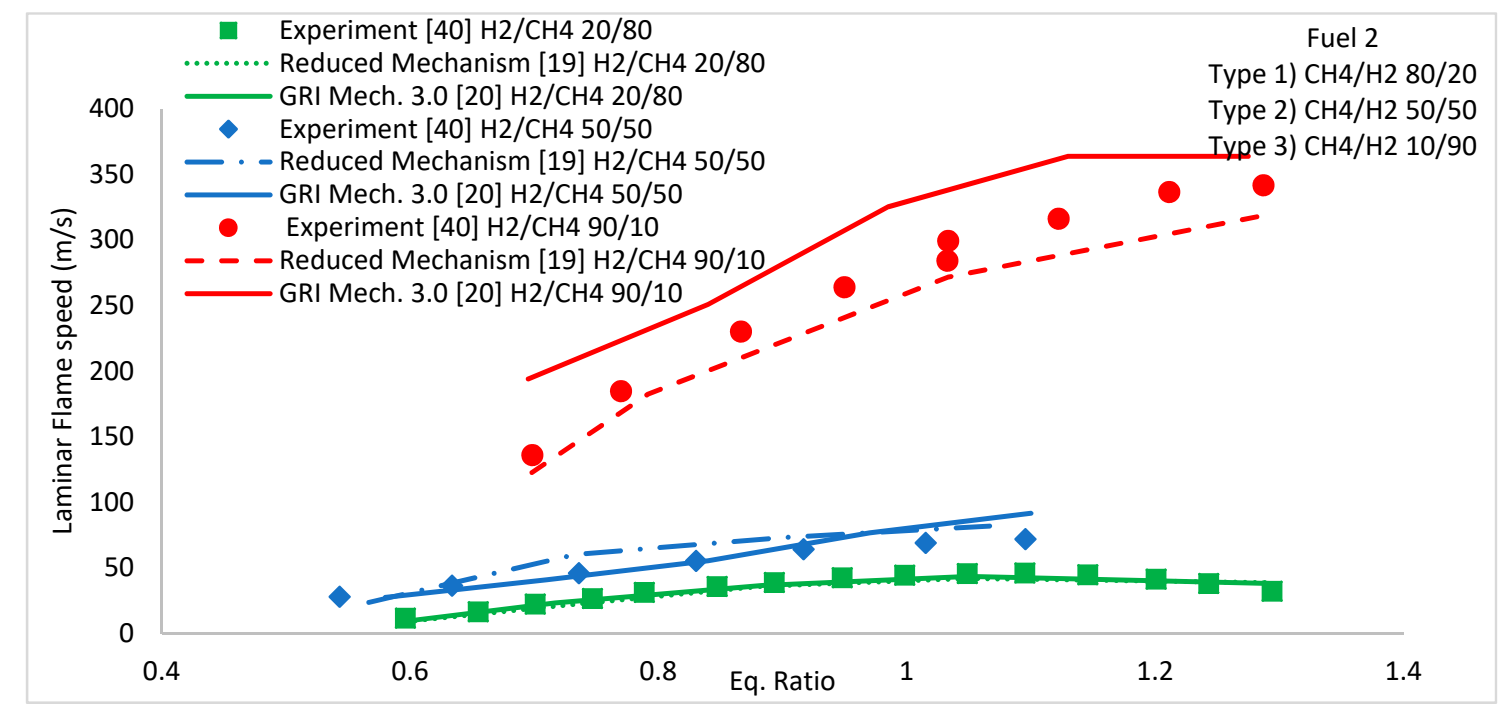

Figure 4. Comparison of the calculated laminar flame speed using the reduced mechanism [19] and GRI Mech. 3.0 [20] and the experimental measurements from Reference [40] for Fuel $2\left(\mathrm{H}_{2} / \mathrm{CH}_{4} 20 / 80 \%\right.$, $50 / 50 \%$ and $90 / 10 \%$ ) at pressure 1 bar, eq.ratio $0.5-1.3$ and temperature $298 \mathrm{~K}$.

Furthermore, according to the results, the richer the mixture and therefore the higher the equivalence ratio, the higher the intensity of the mixture and therefore the higher the laminar flame speed. Additionally, the higher the amount of $\mathrm{CH}_{4}$ in the mixture, the lower the reactivity of the mixture and therefore the lower the laminar flame speed. However, this phenomenon is not only correlated with the higher concentration of $\mathrm{CH}_{4}$ but also with the reduction of $\mathrm{H}_{2}$. Different authors have highlighted the importance of the higher concentration of $\mathrm{H}_{2}$ on the reactivity of the mixture [46-48]. By increasing the amount of $\mathrm{H}_{2}$ in the mixture and therefore reducing $\mathrm{CH}_{4}$, the formation rate of highly reactive $\mathrm{OH}$ radicals is greater and therefore the reactivity of the mixture is faster.

For further investigation of the effect of $\mathrm{CH}_{4}$ and $\mathrm{H}_{2}$ concentration on laminar flame speed, the experimental results obtained by Hermanns et al. [41] for pure methane $\left(\mathrm{CH}_{4} 100 \%\right)$ and $\mathrm{CH}_{4} / \mathrm{H}_{2}$ $85 / 15 \%$ and by Coppens et al. [42] for $\mathrm{CH}_{4} / \mathrm{H}_{2} 70 / 30 \%$ were used. Both authors measured laminar flame speeds at pressure 1 bar, temperature $300 \mathrm{~K}$ and equivalence ratios between 0.6-1.5. The results are presented in Figure 5 and show that both the reduced mechanism [19] and GRI Mech. 3.0 [20] accurately reproduce the experimental results and capture the effects of equivalence ratio and $\mathrm{CH}_{4}$ and $\mathrm{H}_{2}$ concentrations on laminar flame speed. Similar to the results of Figure 4, the higher the equivalence ratio, the higher the laminar flame speed. While on the other hand, the higher the concentration of $\mathrm{CH}_{4}$ and therefore the lower the concentration of $\mathrm{H}_{2}$ in the mixture, the lower the laminar flame speed. For example, the maximum laminar flame speed for $100 \% \mathrm{CH}_{4}$ is approximately $40 \mathrm{~m} / \mathrm{s}$, while for $70 \%$ $\mathrm{CH}_{4}$, the maximum laminar flame speed increases to $50 \mathrm{~m} / \mathrm{s}$. 


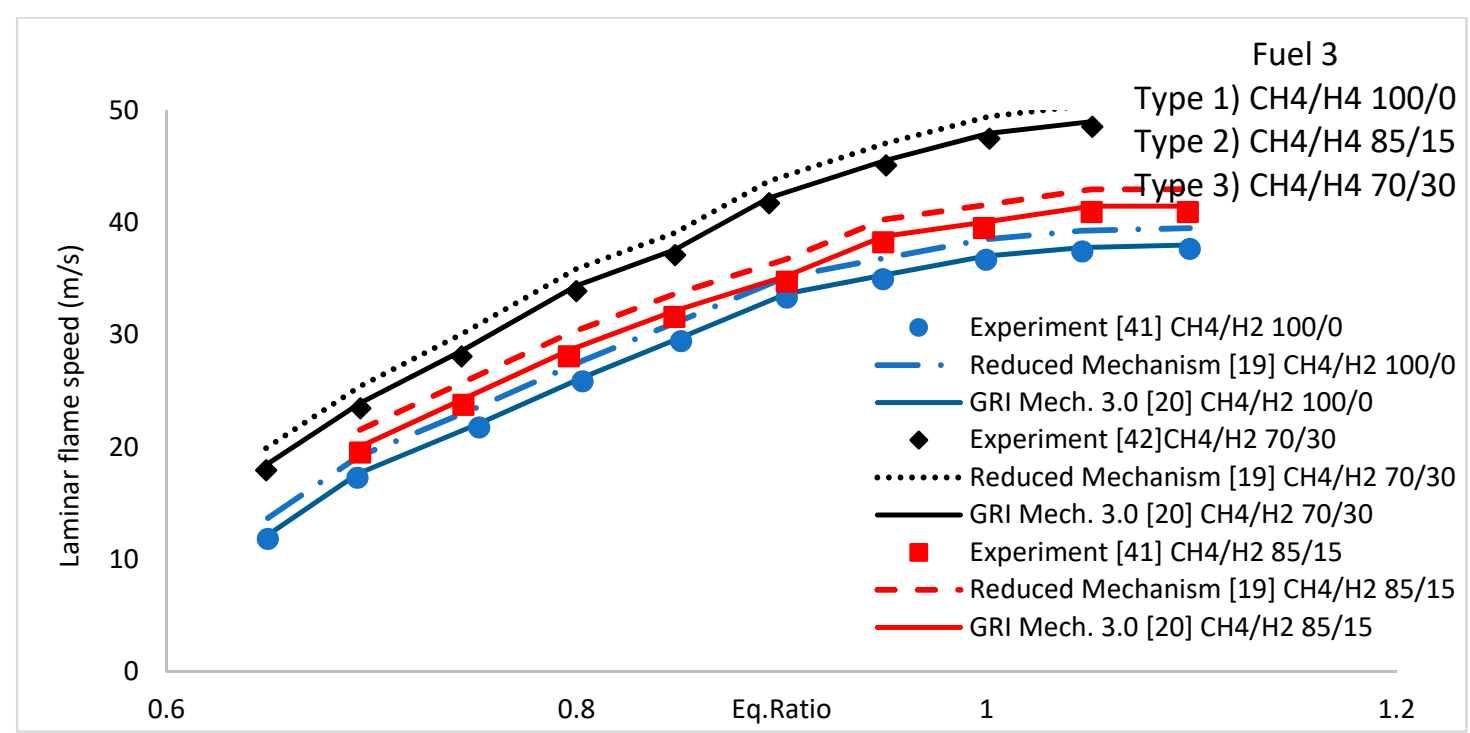

Figure 5. Comparison of the calculated laminar flame speed using the reduced mechanism [19] and GRI Mech. 3.0 [20] and the experimental measurements from References [41,42] for Fuel $3\left(\mathrm{CH}_{4} / \mathrm{H}_{2}\right.$ $100 / 0 \%, 70 / 30 \%$ and $85 / 15 \%$ ) at pressure 1 bar, eq.ratio $0.65-1.1$ and temperature $300 \mathrm{~K}$.

\subsection{2. $\mathrm{H}_{2} / \mathrm{CO} / \mathrm{CH}_{4}$ Fuel Mixture}

The last set of experimental laminar flame speed measurements were obtained from Lapalme et al. [43], Fuel 4, Table 2. The results of the comparison between the numerical and experimental results are presented in Figure 6. The reduced mechanism [19] captures the effect of $\mathrm{CH}_{4}$ concentration and shows a good match with the experimental results at all equivalence ratios for both mixtures. On the other hand, GRI Mech. 3.0 [20] performs very well for both mixtures at lean equivalence ratios but for equivalence ratios higher than 1.0 the numerical results deviate from the experimental measurements.

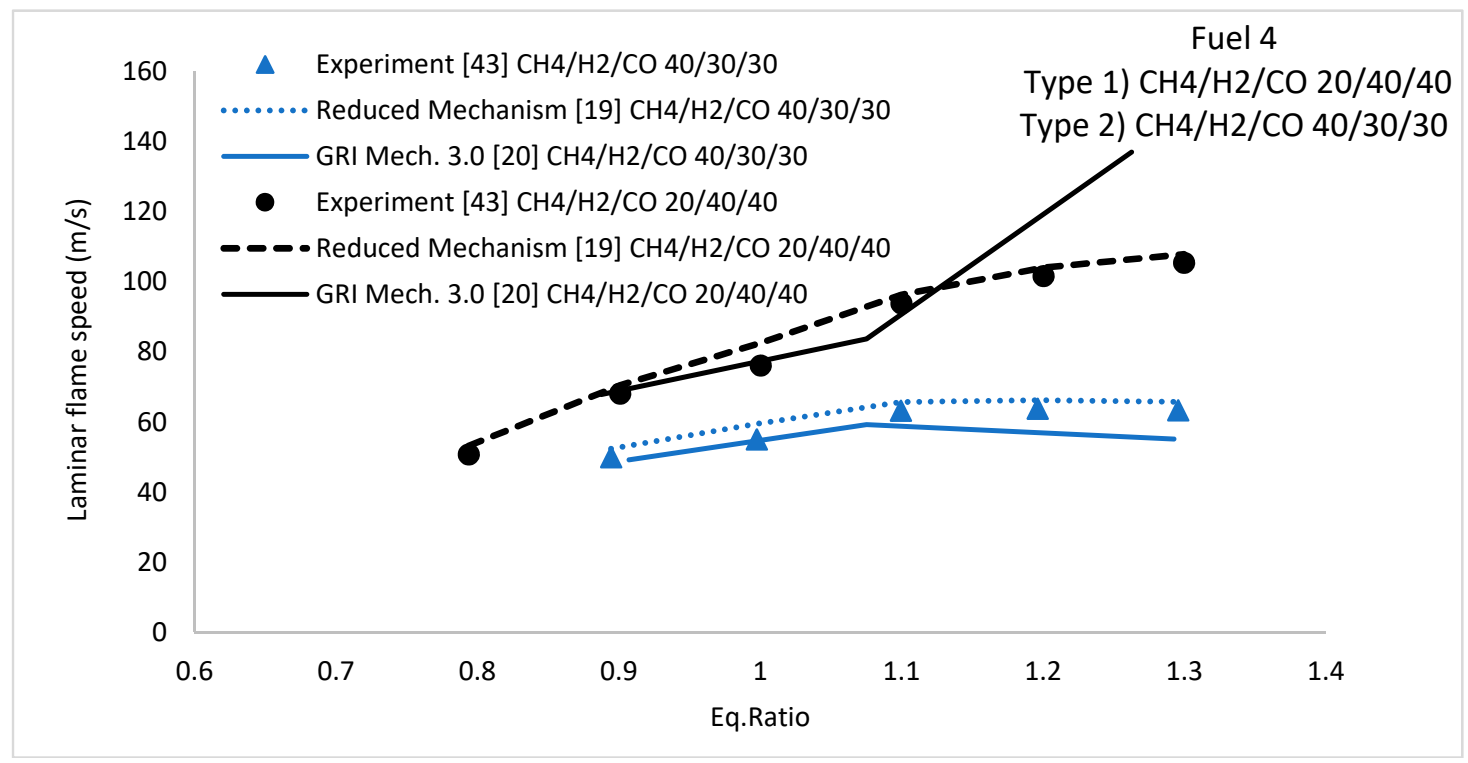

Figure 6. Comparison of the calculated laminar flame speed using the reduced mechanism [19] and GRI Mech. 3.0 [20] and the experimental measurements from Reference [43] for Fuel $4\left(\mathrm{CH}_{4} / \mathrm{H}_{2} / \mathrm{CO}\right.$ $40 / 30 / 30 \%$ and $20 / 40 / 40 \%$ ), at pressure 1 bar, eq.ratio 0.7-1.3 and temperature $295 \mathrm{~K}$.

The effect of $\mathrm{CH}_{4}$ concentration is similar to the effect observed previously for the comparisons presented in Figures 4 and 5. The maximum laminar flame speed for $\mathrm{CH}_{4} / \mathrm{H}_{2} / \mathrm{CO} 40 / 30 / 30 \%$ is 
approximately $65 \mathrm{~m} / \mathrm{s}$, while for $\mathrm{CH}_{4} / \mathrm{H}_{2} / \mathrm{CO} 20 / 40 / 40 \%$ is approximately $110 \mathrm{~m} / \mathrm{s}$. This phenomenon cannot only be attributed to the amount of $\mathrm{CH}_{4}$ included in the mixture but also to the higher concentration of $\mathrm{H}_{2}$. The higher concentration of $\mathrm{H}_{2}$ increases the reactivity of the mixture and therefore increases the laminar flame speed.

\subsection{Species Concentration Profiles}

In order to investigate the oxidation of the fuel during the combustion of different $\mathrm{CH}_{4} / \mathrm{H}_{2}$ mixtures at different combustion conditions, different species concentrations were calculated using the reduced mechanism and compared with experimental measurements obtained from Cong et al. [44]. These authors measured the species concentrations by using a jet-stirred reactor at constant residence time of $120 \mathrm{~ms}$ at pressure $1 \mathrm{~atm}$ and $250 \mathrm{~ms}$ at pressure $10 \mathrm{~atm}$. They pre-heated the fuel before injection while the flow rates were regulated by using thermal controllers. In order to reduce the uncertainties and produce accurate results, a similar approach was used during the simulations setting initial premixed temperature and fuel temperature similar to those used in experiments of [44]. In DARS, the fuel temperature was set to $400 \mathrm{~K}$ to achieve the ignition. By boosting and preheating, the mixture it was possible to obtain flame at very low equivalence ratio.

First, $\mathrm{CH}_{4}$ concentration profiles were calculated for the combustion of $\mathrm{CH}_{4} / \mathrm{H}_{2} 100 / 0 \%$ mixture at pressures 1 and 10 bar, temperatures ranging between $900-1450 \mathrm{~K}$ and equivalence ratios of 0.1 , 0.6 and 1.5. The results are presented in Figure 7, for pressure 1 bar and Figure 8, for pressure 10 bar. As can be seen from the results, the reduced mechanism [19] simulates with relatively low deviation from the experimental results, the concentration profiles of methane at all of the tested conditions, accurately capturing the effect of pressure, equivalence ratio and temperature on methane consumption. At pressure 10 bar, methane is consumed more gradually, enhancing the reactivity of the mixtures in comparison with 1 bar in which it is consumed sharply and rapidly. According to Cong et al. [44], at high pressures, recombination reactions affecting the formation of methane and the metathesis of methane and $\mathrm{OH}$ are more important and lead to lower reactivity of methane.

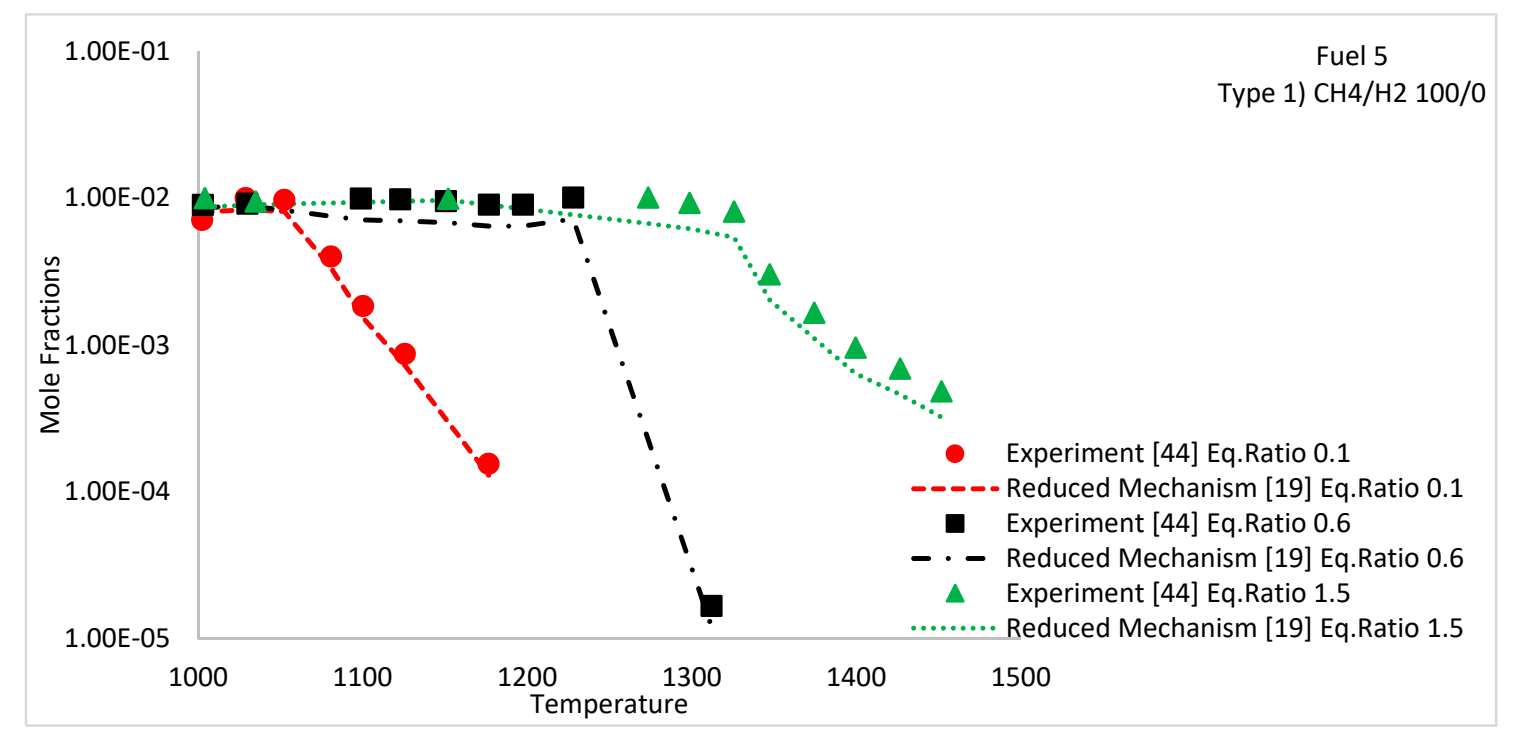

Figure 7. Comparison of the calculated $\mathrm{CH}_{4}$ profiles by using the reduced mechanism [19] and the experimental measurements from Reference [44] for $100 \%$ methane mixture at pressure 1 bar, temperatures $900-1450 \mathrm{~K}$ and eq.ratios $0.1,0.6$ and 1.5 . 


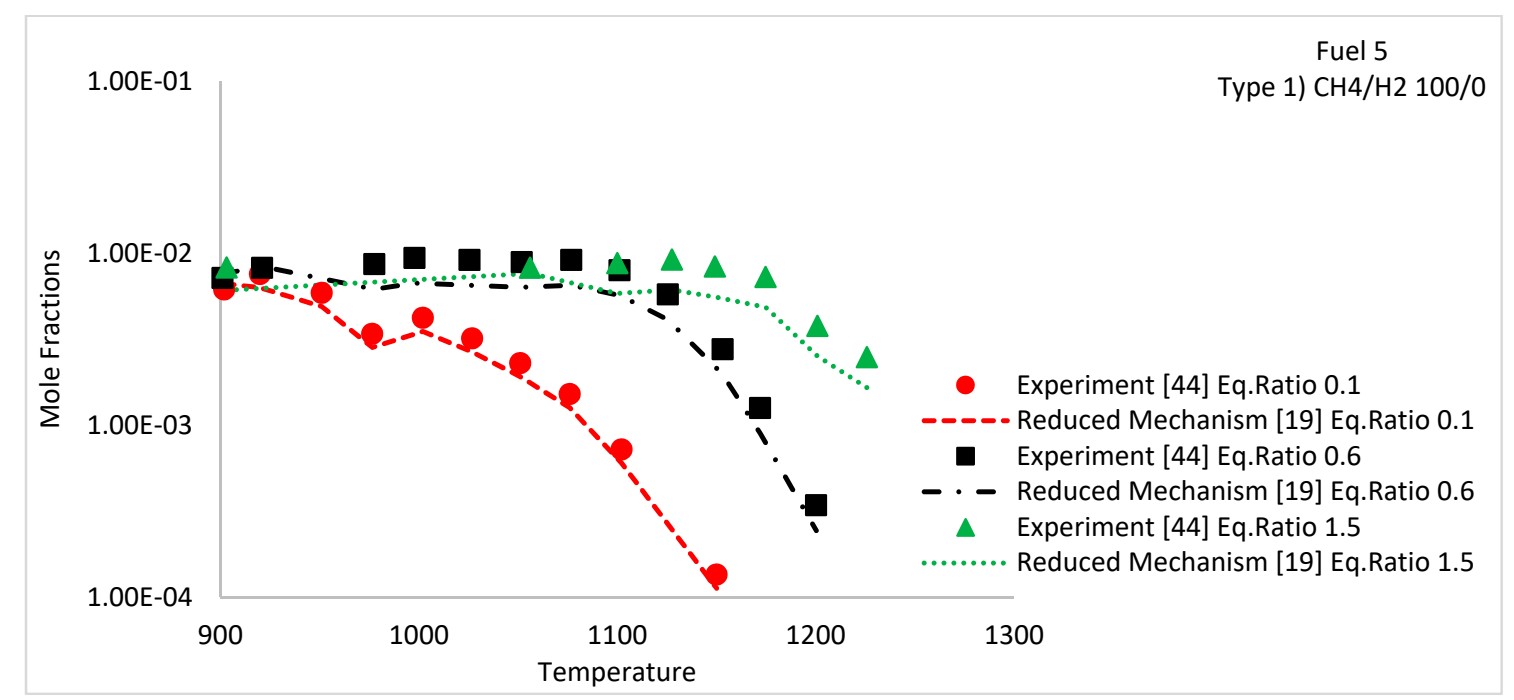

Figure 8. Comparison of the calculated $\mathrm{CH}_{4}$ profiles by using the reduced mechanism [19] and the experimental measurements from Reference [44] for $100 \%$ methane mixture at pressure 10 bar, temperatures $900-1450 \mathrm{~K}$ and eq.ratios $0.1,0.6$ and 1.5 .

It can be seen from the methane concentration profiles, for each equivalence ratio, that methane is reacting at different temperatures. This phenomenon is more obvious at low pressure conditions, as shown in Figure 7. At equivalence ratio 0.1, methane is reacting at temperature $1050 \mathrm{~K}$, at equivalence ratio 0.6 it is reacting at $1220 \mathrm{~K}$ and at equivalence ratio $1.5 \mathrm{it}$ is reacting at $1325 \mathrm{~K}$. This phenomenon is an indicator that the equivalence ratio plays a major role on methane oxidation and is affecting the reactivity of the whole mixture. This is because at different equivalence ratios, different methane-based and hydrogen-based reactions are triggered, leading to faster or slower formation of $\mathrm{OH}$ species that are responsible for the increase in the temperature and the reactivity of the mixture [44,46]. Therefore, the mixture is reacting at different temperatures at different equivalence ratios.

For further investigation, the concentration profiles of $\mathrm{H}_{2}$ and $\mathrm{CH}_{4}$ during the combustion of $\mathrm{CH}_{4} / \mathrm{H}_{2} 50 / 50 \%$ at temperature $975-1150 \mathrm{~K}$, pressure 1 bar and equivalence ratios 0.1 and 0.6 , have also been calculated and compared with the experimental measurements obtained from Cong et al. [44]. The results presented in Figure 9 show that the reduced mechanism accurately simulates the experimental results and clearly captures the effect of temperature on both $\mathrm{H}_{2}$ and $\mathrm{CH}_{4}$ concentration profiles; the higher the temperature, the lower the mole fractions of both $\mathrm{H}_{2}$ and $\mathrm{CH}_{4}$. By comparing the results of the methane concentration profiles for the pure methane mixture, presented in Figure 7, with the results in Figure 9, it can be seen that in the presence of hydrogen, methane was consumed more gradually. This is because different hydrogen based reactions are responsible for the initiation of mixture oxidation and the formation of $\mathrm{OH}$. They trigger methane-based recombination reactions, which change the chemical stability of the combustion process.

Finally, in order to analyse the effect of $\mathrm{H}_{2}$ on $\mathrm{CH}_{4}$ conversion, the experimental results from Dufour et al. [45] were used, Fuel 6, Table 2. Both experimental and simulated results are presented in Figure 10 and highlight the effect of $\mathrm{H}_{2}$ on $\mathrm{CH}_{4}$ conversion: The higher is the initial mole fraction of $\mathrm{H}_{2}$, the lower is the $\mathrm{CH}_{4}$. More specifically, by increasing the initial mole fraction of $\mathrm{H}_{2}$ from 16 to $32 \mathrm{vol} \%$, the conversion rate of $\mathrm{CH}_{4}$ is reduced from about $55 \mathrm{vol} \%$ to $35 \mathrm{vol} \%$. 

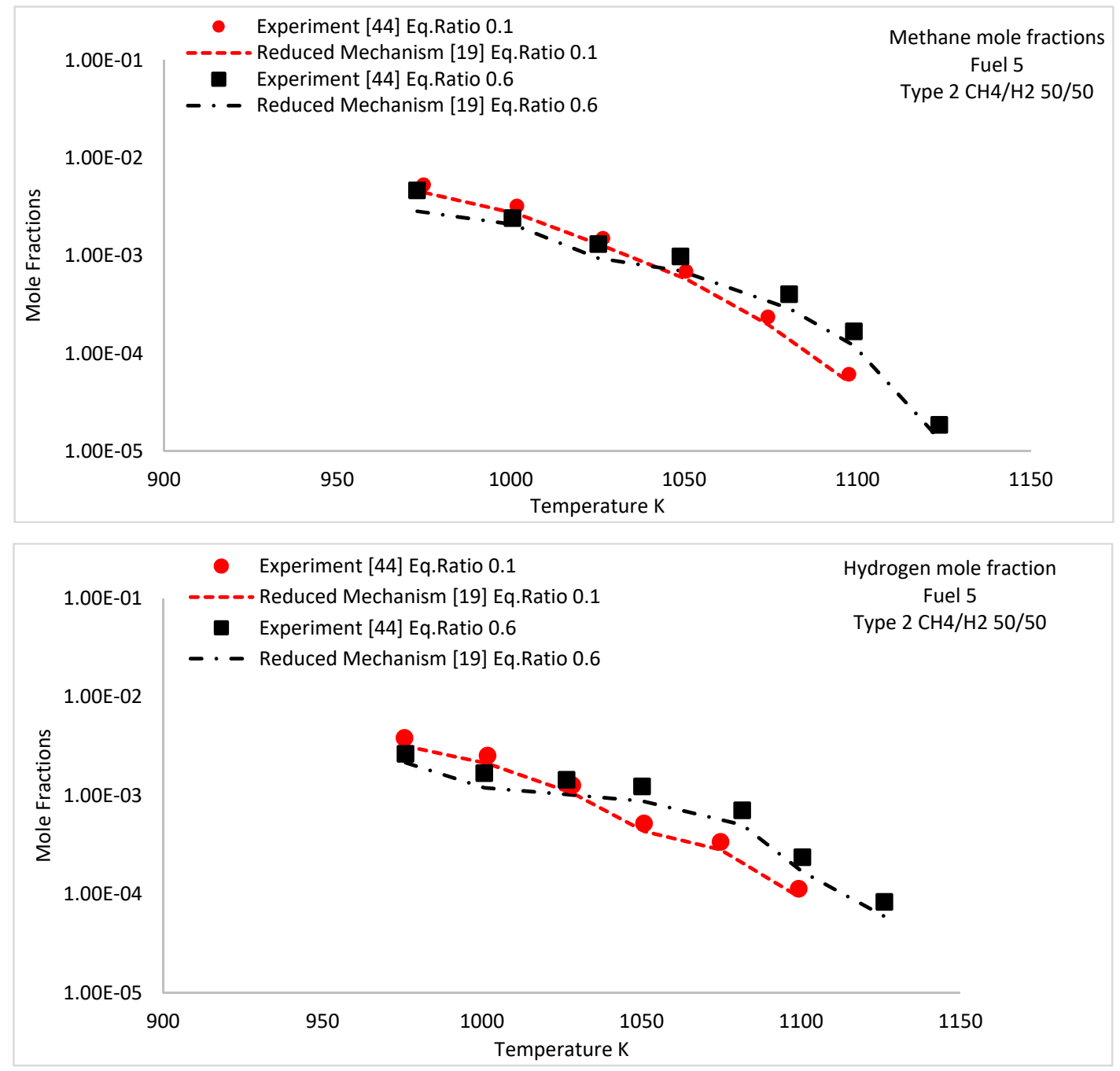

Figure 9. Comparison of the calculated $\mathrm{CH}_{4}$ (top) and $\mathrm{H}_{2}$ (bottom) profiles by using the reduced mechanism [19] and the experimental measurements from Reference [44] for $\mathrm{CH}_{4} / \mathrm{H}_{2}$ 50/50 mixture at pressure 1 bar, temperatures $950-1125 \mathrm{~K}$ and eq.ratios 0.1 and 0.6 .

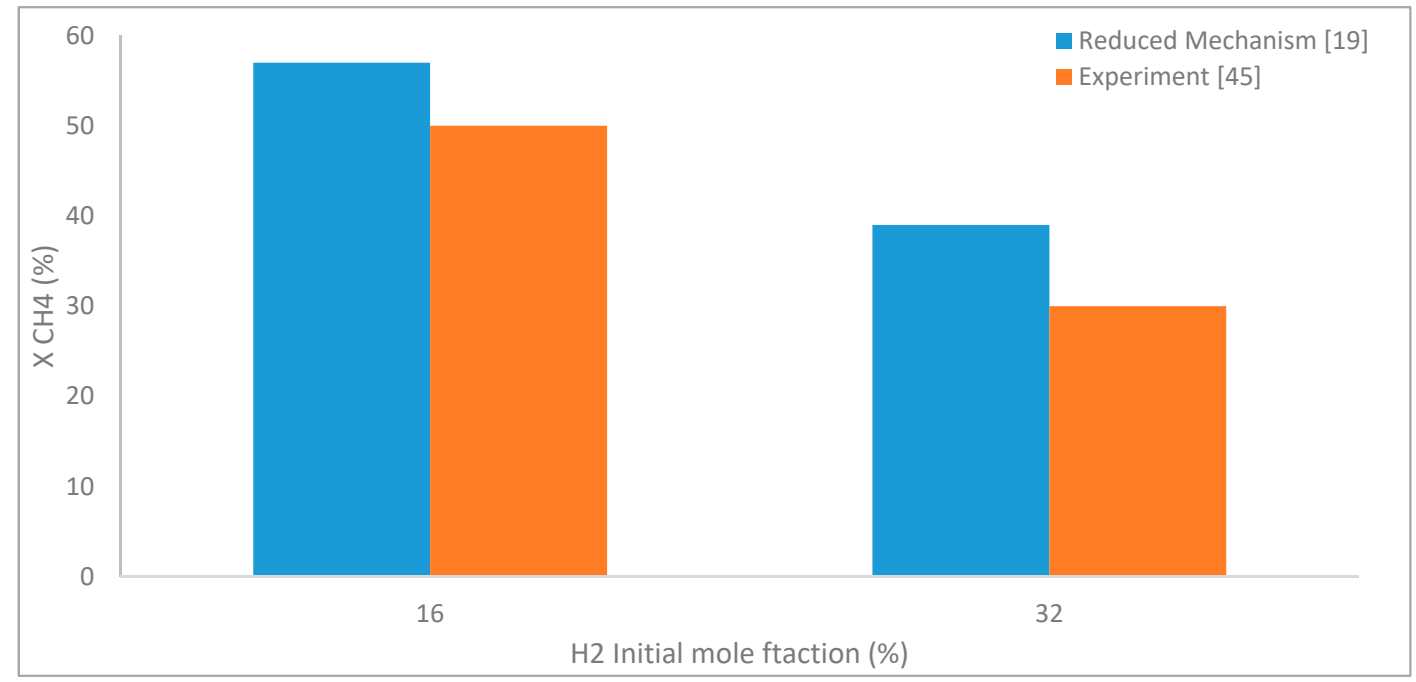

Figure 10. Effect of $\mathrm{H}_{2}$ mole fraction on the conversion of $\mathrm{CH}_{4}$ using the reduced mechanism [19] and the experimental data from Reference [45]. 


\subsection{Chemical Detailed Analysis}

In order to investigate in detail the reactions affecting methane oxidation during syngas and $\mathrm{H}_{2} / \mathrm{CH}_{4}$ mixture combustion, a reaction sensitivity study was conducted. This sensitivity study is separated into two parts: first, the effect of equivalence ratio on methane oxidation was investigated and important reactions were identified and analysed; second, the important reactions affecting methane-rich $\mathrm{H}_{2} / \mathrm{CH}_{4}$ and hydrogen-rich $\mathrm{H}_{2} / \mathrm{CH}_{4}$ mixture combustion were identified and analysed.

\subsection{1. $\mathrm{H}_{2} / \mathrm{CO} / \mathrm{CH}_{4}$ Reaction Sensitivity}

For the first investigation, reaction sensitivity analysis was conducted using fuel $\mathrm{H}_{2} / \mathrm{CO} / \mathrm{CH}_{4}$ $30 / 30 / 40 \%$, at pressure $10 \mathrm{bar}$, temperature $1125 \mathrm{~K}$ and equivalence ratios $0.5,1.0$ and 1.5 . The results for the ten most sensitive reactions are shown in Figure 11. Hydrogen and methane-based reactions are found to be the dominant reactions, driving the combustion process, more specifically, hydrogen-based reactions $\mathrm{H}_{2} \mathrm{O}_{2}+\mathrm{M}=\mathrm{OH}+\mathrm{OH}+\mathrm{M}, \mathrm{H}_{2} \mathrm{O}_{2}+\mathrm{H}=\mathrm{H}_{2}+\mathrm{HO}_{2}, \mathrm{H}+\mathrm{O}_{2}=\mathrm{OH}+\mathrm{O}, \mathrm{H}_{2}+\mathrm{O}=\mathrm{OH}+\mathrm{O}$, $\mathrm{OH}+\mathrm{HO}_{2}=\mathrm{H}_{2} \mathrm{O}+\mathrm{O}_{2}$ and methane-based reactions $\mathrm{CH}_{4}+\mathrm{O}_{2}=\mathrm{CH}_{3}+\mathrm{HO}_{2}, \mathrm{CH}_{4}+\mathrm{HO}_{2}=\mathrm{CH}_{3}+$ $\mathrm{H}_{2} \mathrm{O}_{2}, \mathrm{CH}_{4}+\mathrm{OH}=\mathrm{CH}_{3}+\mathrm{H}_{2} \mathrm{O}, \mathrm{CH}_{3}+\mathrm{O}_{2}=\mathrm{CH}_{2} \mathrm{O}+\mathrm{OH}, \mathrm{CO}+\mathrm{OH}=\mathrm{CO}_{2}+\mathrm{H}$.

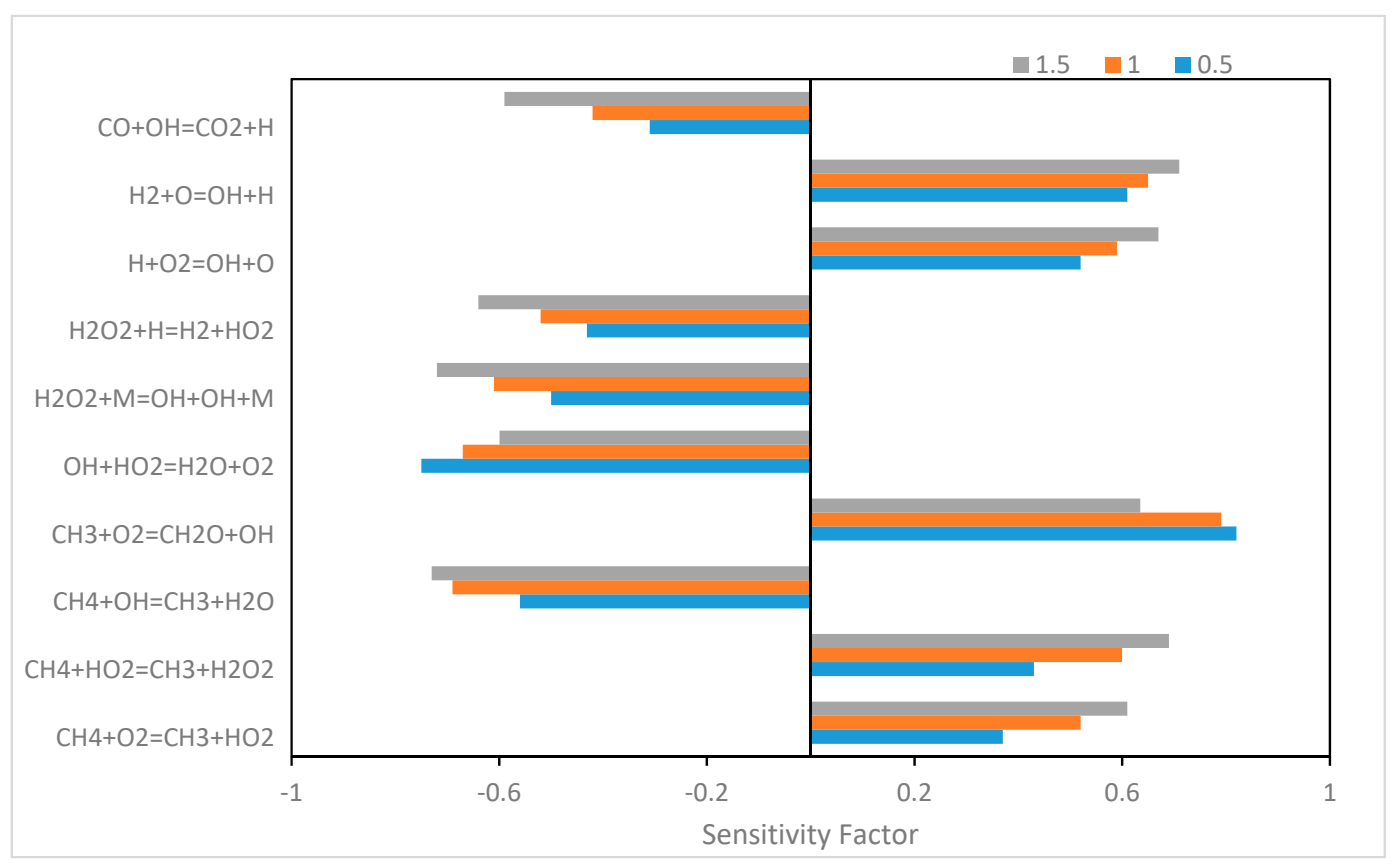

Figure 11. Ten most sensitive reactions for Fuel 6: $\mathrm{H}_{2} / \mathrm{CO} / \mathrm{CH}_{4} 30 / 30 / 40 \%$, at pressure 10 bar, temperature $1125 \mathrm{~K}$ and equivalence ratios $0.5,1.0$ and 1.5 .

Hydrogen-Based Reactions

All of the hydrogen-based reactions highlighted in the sensitivity analysis are directly or indirectly related to the formation or consumption of highly reactive $\mathrm{OH}$ radicals. As it was already mentioned in this study, many researchers characterize $\mathrm{OH}$ as an indicator of the combustion occurrence due to the fact that the formation rate of $\mathrm{OH}$ is directly connected to the temperature and fuel reactivity variations: the higher the formation rate of $\mathrm{OH}$, the faster the reactivity and the higher the intensity of the mixture and therefore the temperature.

Each hydrogen-based reaction presented in the sensitivity analysis is discussed below.

$$
\text { (R19) } \mathrm{H}_{2} \mathrm{O}_{2}+\mathrm{M}=\mathrm{OH}+\mathrm{OH}+\mathrm{M}
$$

According to many authors [49-51] the dissociation of $\mathrm{H}_{2} \mathrm{O}_{2}$ radicals is the central kinetics feature in the operation of compression-ignition engines and has a major role on the occurrence of abnormal 
combustion phenomena. R19 is one of the most important reactions affecting the decomposition of $\mathrm{H}_{2} \mathrm{O}_{2}$. By the decomposition of $\mathrm{H}_{2} \mathrm{O}_{2}$ via R19, secondary reactions that are responsible for the formation of highly reactive $\mathrm{OH}$ are triggered. As it can be seen from Figure 11, R19 is very sensitive to the equivalence ratio: the higher the equivalence ratio, the higher the sensitivity of the specific reaction. This is because at higher equivalence ratios, the $\mathrm{H}_{2} \mathrm{O}_{2} / \mathrm{OH}$ ratio decreased due to the faster formation of $\mathrm{OH}$ and therefore the faster dissociation of $\mathrm{H}_{2} \mathrm{O}_{2}$ via R19. That leads to an enhanced chain-initiation process through different hydrogen-based reactions, such as $\mathrm{H}_{2}+\mathrm{O}_{2}=\mathrm{OH}+\mathrm{OH}$ and $\mathrm{H}_{2}+\mathrm{O}_{2}=$ $\mathrm{H}+\mathrm{HO}_{2}$, ensuring the occurrence of subsequent chain-branching reactions along with an increase in the $\mathrm{OH}$ concentration. Detailed analysis of R19 and investigation of how different reaction rates affecting the formation or dissociation of $\mathrm{OH}$ and therefore the $\mathrm{H}_{2} \mathrm{O}_{2}$ ratio are provided in a previous study [19].

$$
\text { (R30) } \mathrm{H}_{2} \mathrm{O}_{2}+\mathrm{H}=\mathrm{H}_{2}+\mathrm{HO}_{2}
$$

R30 is one of the leading reactions under low temperature/high pressure conditions $[19,27]$. This reaction is responsible for the consumption of one $\mathrm{HO}_{2}$ radical which in turn leads to the production of one $\mathrm{H}_{2} \mathrm{O}_{2}$ molecule. $\mathrm{H}_{2} \mathrm{O}_{2}$ will then be consumed via $\mathrm{R} 19$ for the formation of high reactive $\mathrm{OH}$ radicals [27]. Therefore, it can be said that $\mathrm{R} 30$ is indirectly affecting the reactivity of the mixture.

$$
\text { (R20) } \mathrm{H}+\mathrm{O}_{2}=\mathrm{OH}+\mathrm{O}
$$

For a chemical kinetics mechanism, R20 is one of the most important reactions that has to be included. R20 is a leading controlling reaction, responsible for the control of the fuels oxidation [27]. The interaction between hydrogen and oxygen leads to the formation of $\mathrm{OH}$. Especially for richer mixtures (high equivalence ratio) this reaction plays a critical role in controlling, not only the formation of $\mathrm{OH}$ and therefore the reactivity of the mixture but also the general oxidation process of the fuel.

$$
\text { (R21) } \mathrm{H}_{2}+\mathrm{O}=\mathrm{OH}+\mathrm{O}
$$

Another reaction responsible for the control of the fuels oxidation and the production of high reactive $\mathrm{OH}$ radicals is $\mathrm{R} 21$. $\mathrm{R} 21$ is combined with $\mathrm{R} 20$, in order to control the interactions between oxygen and hydrogen. Different researchers have analysed the behaviour of R20 and R21, focusing on rich mixtures and high temperature conditions [52-54]. They showed that at rich mixture/high temperature conditions both of these reactions have high sensitivity, leading to faster consumption of oxygen and production of $\mathrm{OH}$. This statement is in agreement with the results from the sensitivity analysis presented in Figure 11, in which R20 and R21 show higher sensitivity factors as the equivalence ratio increases. Moreover, the interaction between R20 and R21, triggers other controlling reactions, for example, $\mathrm{R} 22 \mathrm{H}_{2}+\mathrm{OH}=\mathrm{H}_{2} \mathrm{O}+\mathrm{H}$, responsible for consumption of $\mathrm{OH}$ and reduction of mixture reactivity.

$$
\text { (R28) } \mathrm{OH}+\mathrm{HO}_{2}=\mathrm{H}_{2} \mathrm{O}+\mathrm{O}_{2}
$$

$\mathrm{R} 28$ is an important reaction responsible for the consumption of $\mathrm{OH}$ high reactive radicals and the production of $\mathrm{H}_{2} \mathrm{O}$. Therefore, it can be said that this reaction decreases the reactivity of the mixture. As shown by Keromnes et al. [27], R28 is very sensitive to fuel lean flames and its sensitivity decreases as the equivalence ratio increases. This statement can be observed from the results of Figure 11 in which, the sensitivity coefficient of R28 at the equivalence ratio 0.5 , is approximately -0.75 , at equivalence ratio 1.0 is -0.65 and at equivalence ratio 1.5 is approximately -0.60 .

\section{Methane-Based Reactions}

Five different methane-based reactions were identified as very important at all of the equivalence ratios tested; R1, R2, R3, R4 and R5. However, for each equivalence ratio, the sensitivity factor of the reactions changed significantly. For example, for a lean mixture (equivalence ratio 0.5 ), the sensitivity factor of R4 is approximately 0.6 , while at equivalence ratio 1.0 it increases to 0.79 and at equivalence 
ratio 1.5 it increases to 0.85 . This is because the formation of $\mathrm{CH}_{2} \mathrm{O}$ is much faster and has a greater effect on the reactivity of the mixture and the combustion process at lean mixtures in comparison with the rich mixture conditions $[44,46]$.

Furthermore, at moderated combustion conditions (temperature between $900-1450 \mathrm{~K}$ and pressure between 1-10 bar), methane recombination reactions have been found to play a critical role in combustion control [44]. According to Cong [44], methane recombination reactions are mainly responsible for the consumption of $\mathrm{CH}_{4}$ by metathesis with high reactive $\mathrm{OH}$ radicals and their sensitivity increases with equivalence ratio. This statement is confirmed from the results presented in Figure 11, which show that recombination reactions such as $\mathrm{CH}_{4}+\mathrm{OH}=\mathrm{CH}_{3}+\mathrm{H}_{2} \mathrm{O}, \mathrm{CH}_{4}+\mathrm{O}_{2}=\mathrm{CH}_{3}+\mathrm{HO}_{2}$ and $\mathrm{CH}_{4}+\mathrm{HO}_{2}=$ $\mathrm{CH}_{3}+\mathrm{H}_{2} \mathrm{O}_{2}$, have higher sensitivity factors at richer mixture conditions (equivalence ratio 1.5) while at lower equivalence ratio 0.5 their sensitivity factor is lower. The importance of each methane-based reaction is presented in detail below.

$$
\text { (R3) } \mathrm{CH}_{4}+\mathrm{OH}=\mathrm{CH}_{3}+\mathrm{H}_{2} \mathrm{O}
$$

$\mathrm{R} 3$ is one of the major recombination reactions especially at high pressure/rich mixture conditions. The oxidation of $\mathrm{CH}_{4}$ through $\mathrm{R} 3$ is responsible for the slow formation of $\mathrm{CH}_{3}$ by the consumption of $\mathrm{CH}_{4}$ and high reactive $\mathrm{OH}$ and the production of more water vapor [55]. This interaction will make the fuel mixture less chemically sensitive to further concentration of $\mathrm{H}_{2} \mathrm{O}$ but on the other hand, will increase the specific heat capacity of the product, since $\mathrm{CH}_{4}$ is directly oxidized for the production of $\mathrm{H}_{2} \mathrm{O}$. This results in the fuel mixture becoming more thermally sensitive [50].

$$
\text { (R1) } \mathrm{CH}_{4}+\mathrm{O}_{2}=\mathrm{CH}_{3}+\mathrm{HO}_{2}
$$

$\mathrm{R} 1$ is a major initiation reaction as it triggers oxidation of methane with molecular oxygen and leads to the production of $\mathrm{HO}_{2}$ and $\mathrm{CH}_{3} . \mathrm{HO}_{2}$ then attacks $\mathrm{CH}_{4}$ via $\mathrm{R} 2$, starting the main fuel oxidation path for the formation of $\mathrm{H}_{2} \mathrm{O}_{2}$. On the other hand, the produced $\mathrm{CH}_{3}$ is reacting with molecular oxygen via $\mathrm{R} 4$ forming formaldehyde and high reactive $\mathrm{OH}$ radicals resulting in the ignition initiation of methane. Moreover, the adverse $\mathrm{R} 1, \mathrm{CH}_{3}+\mathrm{HO}_{2}=\mathrm{CH}_{4}+\mathrm{O}_{2}$ is characterized as an important inhibiting reaction due to the fact that $\mathrm{CH}_{3}$ is drastically consumed, preventing the interaction with $\mathrm{R} 2$ for the production of $\mathrm{OH}$ radicals [56].

$$
\text { (R2) } \mathrm{CH}_{4}+\mathrm{HO}_{2}=\mathrm{CH}_{3}+\mathrm{H}_{2} \mathrm{O}_{2}
$$

$\mathrm{HO}_{2}$ radicals that have been produced via $\mathrm{R} 1$, interact with $\mathrm{CH}_{4}$ via $\mathrm{R} 2$ for the formation of $\mathrm{CH}_{3}$ and $\mathrm{H}_{2} \mathrm{O}_{2}$. The produced $\mathrm{H}_{2} \mathrm{O}_{2}$ is then consumed by hydrogen-based and methane-based reactions, for example $\mathrm{R} 19$, for the formation of high reactive $\mathrm{OH}$ radicals and the initiation of the fuel ignition. Moreover, the produced $\mathrm{CH}_{3}$ interacts with $\mathrm{O}_{2}$ via $\mathrm{R} 4$ for the production of formaldehyde and $\mathrm{OH}[56,57]$. Therefore, it can be said that $\mathrm{R} 2$ is an intermediate reaction that affects the production of $\mathrm{OH}$ via the production of $\mathrm{H}_{2} \mathrm{O}_{2}$ and $\mathrm{CH}_{3}$. Furthermore, at higher equivalence ratios, the sensitivity of $\mathrm{R} 2$ is also higher.

$$
\text { (R4) } \mathrm{CH}_{3}+\mathrm{O}_{2}=\mathrm{CH}_{2} \mathrm{O}+\mathrm{OH}
$$

$\mathrm{R} 4$ is one of the most important reactions in the $\mathrm{CH}_{4}$ oxidation process and is responsible for accelerating methane ignition occurrence. Different researchers $[58,59]$ have used R4 for the accurate prediction of methane ignition delay time. The interaction between $\mathrm{CH}_{3}$ and $\mathrm{O}_{2}$, is a key intermediate in the combustion of multicomponent syngas mixtures and natural gas as it forms $\mathrm{CH}_{2} \mathrm{O}$ and high reactive $\mathrm{OH}[27,29,59,60]$. This reaction has a strange and complex temperature dependence especially at a temperature range between $800-1300 \mathrm{~K}$ and may lead to abnormal combustion phenomena. This is the reason many researchers have used various rate constants in order to express this temperature dependence and accurately predict methane auto-ignition and knocking phenomena $[27,60]$. For example, for the same temperature range $(800-1100 \mathrm{~K})$ the rate constant used 
in the San Diego mechanism [61] for R4 is around 42 times higher than the rate constant used in the detailed GRI Mech. 3.0 [20]. Furthermore, R4 is very sensitive to the equivalence ratio. As it was highlighted by Cong et al. [44], at lean mixtures the production of $\mathrm{CH}_{2} \mathrm{O}$ is faster and therefore the sensitivity of $\mathrm{R} 4$ at lower equivalence ratios is higher than that for rich fuel mixtures.

\subsection{2. $\mathrm{H}_{2} / \mathrm{CH}_{4}$ Reaction Sensitivity}

For the investigation of the important reactions affecting methane-rich $\mathrm{H}_{2} / \mathrm{CH}_{4}$ mixture combustion and hydrogen-rich $\mathrm{H}_{2} / \mathrm{CH}_{4}$ mixture combustion, a second reaction sensitivity analysis was performed. For this sensitivity analysis, two different $\mathrm{CH}_{4} / \mathrm{H}_{2}$ mixtures were used: (a) $\mathrm{H}_{2} / \mathrm{CH}_{4} 20 / 80 \%$ and (b) $\mathrm{H}_{2} / \mathrm{CH}_{4} 80 / 20 \%$. For both fuel mixtures, sensitivity analysis was conducted at pressure $10 \mathrm{bar}$, equivalence ratio 0.5 and temperature $1100 \mathrm{~K}$. The results are presented in Figure 12. It is very important to mention that the scope of this reaction sensitivity analysis was to compare the important reactions for methane-rich and hydrogen-rich mixtures and therefore the absolute sensitivity coefficient was used. For that reason, no negative value sensitivity coefficient is presented in Figure 12.

According to the results, similar reactions have been highlighted as important for both mixtures. More specifically, hydrogen-based reactions $\mathrm{H}_{2} \mathrm{O}_{2}+\mathrm{M}=\mathrm{OH}+\mathrm{OH}+\mathrm{M}, \mathrm{H}_{2} \mathrm{O}_{2}+\mathrm{H}=\mathrm{H}_{2}+\mathrm{HO}_{2}$, $\mathrm{H}+\mathrm{O}_{2}=\mathrm{OH}+\mathrm{O}, \mathrm{H}_{2}+\mathrm{O}=\mathrm{OH}+\mathrm{O}$, methane-based reactions $\mathrm{CH}_{4}+\mathrm{O}_{2}=\mathrm{CH}_{3}+\mathrm{HO}_{2}, \mathrm{CH}_{4}+\mathrm{OH}$ $=\mathrm{CH}_{3}+\mathrm{H}_{2} \mathrm{O}, \mathrm{CH}_{3}+\mathrm{O}_{2}=\mathrm{CH}_{2} \mathrm{O}+\mathrm{OH}$ and $\mathrm{CO}+\mathrm{OH}=\mathrm{CO}_{2}+\mathrm{H}$. The main difference is that for $\mathrm{CH}_{4} / \mathrm{H}_{2} 80 / 20 \%$, (R5) $\mathrm{CH}_{2} \mathrm{O}+\mathrm{OH}=\mathrm{HCO}+\mathrm{H}_{2} \mathrm{O}$ and (R1) $\mathrm{CH}_{4}+\mathrm{HO}_{2}=\mathrm{CH}_{3}+\mathrm{H}_{2} \mathrm{O}_{2}$ are highlighted as important and have a very high sensitivity coefficients ( 0.55 and 0.8 respectively), while for $\mathrm{CH}_{4} / \mathrm{H}_{2}$ $20 / 80 \%$, (R5) and (R1) are not presented and have been replaced by (R28) $\mathrm{OH}+\mathrm{HO}_{2}=\mathrm{H}_{2} \mathrm{O}+\mathrm{O}_{2}$ and (R26) $\mathrm{HO}_{2}+\mathrm{H}=\mathrm{OH}+\mathrm{OH}$. R28 is an inhibiting reaction as it decreases the reactivity of the mixture and controls the formation rate of $\mathrm{OH}$ radicals, while (R26) is responsible for the production of two $\mathrm{OH}$ radicals and increases the reactivity of the mixture. Both of these reactions have been highlighted by many researchers as being very important during the combustion of mixtures with high hydrogen content.

For mixture $\mathrm{CH}_{4} / \mathrm{H}_{2} 80 / 20 \%$, methane-based reactions have the highest sensitivity coefficient and therefore it can be said that they have more influence on the combustion process. For example, reaction $\mathrm{CH}_{3}+\mathrm{O}_{2}=\mathrm{CH}_{2} \mathrm{O}+\mathrm{OH}$, which is responsible for the rapid initiation of methane oxidation, has the highest sensitivity factor of 0.87 , followed by reactions $\mathrm{CH}_{4}+\mathrm{OH}=\mathrm{CH}_{3}+\mathrm{H}_{2} \mathrm{O}$ with sensitivity factor of 0.76 and $\mathrm{CH}_{4}+\mathrm{HO}_{2}=\mathrm{CH}_{3}+\mathrm{H}_{2} \mathrm{O}_{2}$ with sensitivity factor of 0.74 . On the other hand, $\mathrm{CH}_{4} / \mathrm{H}_{2}$ $20 / 80 \%$ shows an opposite trend and hydrogen based reactions have the highest sensitivity factor and drive the combustion process. For example, reactions $\mathrm{H}_{2}+\mathrm{O}=\mathrm{OH}+\mathrm{O}$ and $\mathrm{H}_{2} \mathrm{O}_{2}+\mathrm{M}=\mathrm{OH}+$ $\mathrm{OH}+\mathrm{M}$ have sensitivity factors of 0.88 and 0.85 respectively.

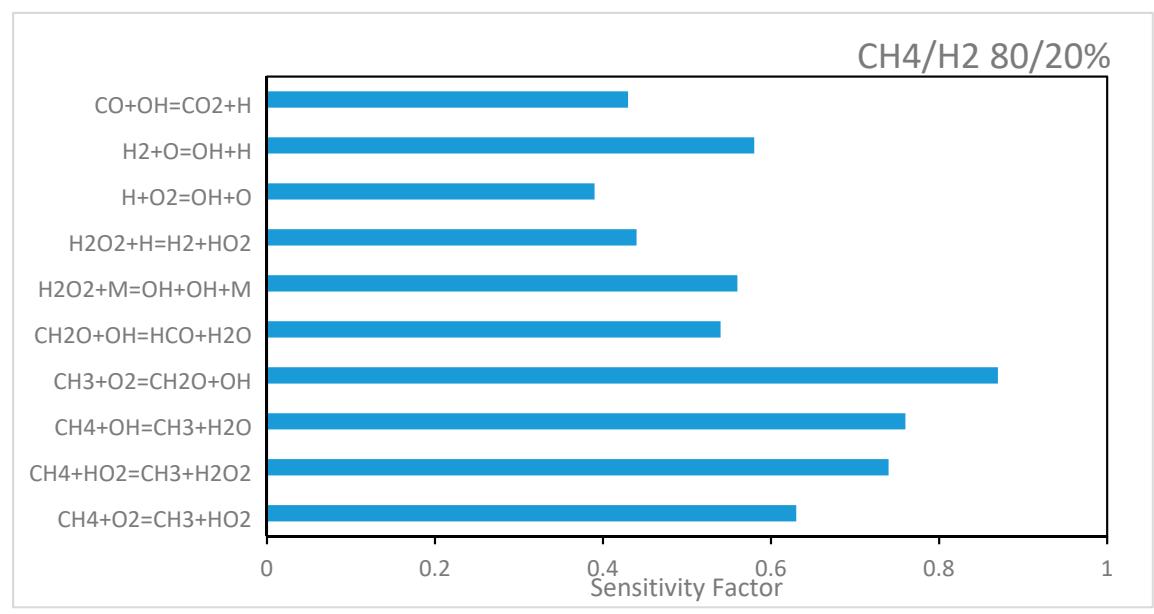

(a)

Figure 12. Cont. 


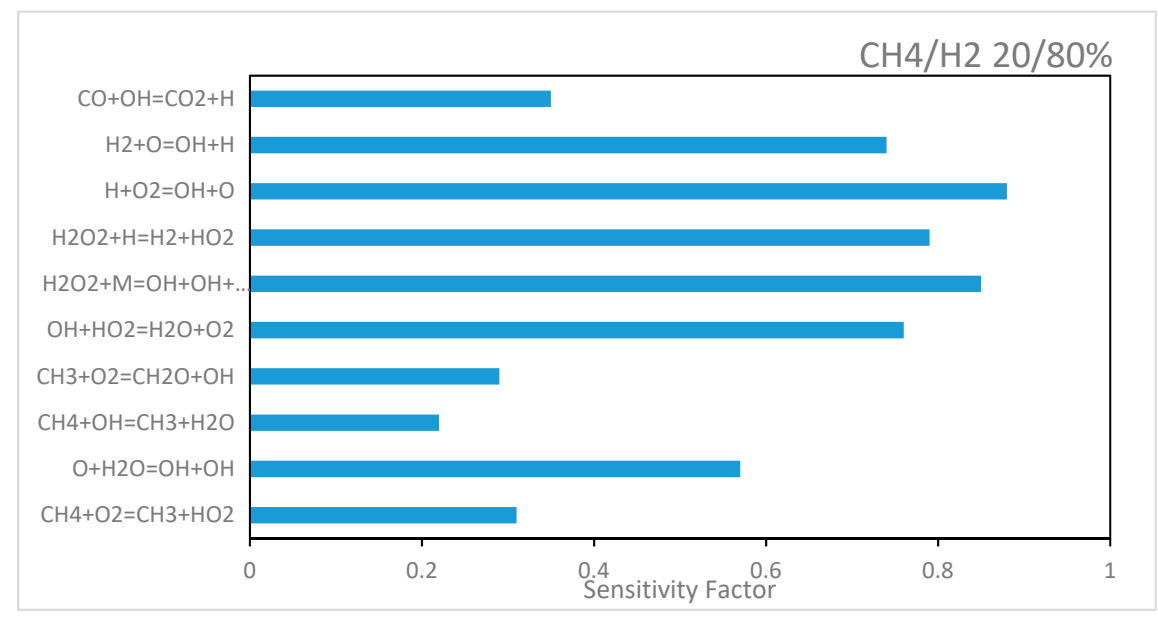

(b)

Figure 12. Ten most sensitive reactions for (a) Fuel 7, $\mathrm{CH}_{4} / \mathrm{H}_{2} 80 / 20 \%$ and (b) Fuel 7, $\mathrm{CH}_{4} / \mathrm{H}_{2} 20 / 80 \%$, at pressure 10 bar, temperature $1100 \mathrm{~K}$ and equivalence ratio 0.5 .

\section{Conclusions}

During this study, the effects of $\mathrm{CH}_{4}$ and $\mathrm{H}_{2}$ concentrations on the combustion of $\mathrm{H}_{2} / \mathrm{CH}_{4}$ and multicomponent syngas mixtures have been investigated using a reduced chemical kinetics mechanism [19]. The simulated results were compared with experimental measurements collected from the literature for laminar flame speed and ignition delay time for different $\mathrm{H}_{2} / \mathrm{C}_{4}$ and $\mathrm{H}_{2} / \mathrm{CO} / \mathrm{CH}_{4}$ mixtures.

For ignition delay times, the higher concentration of $\mathrm{CH}_{4}$ worked as an inhibitor for the mixtures reactivity and resulted in a significant increase of the ignition delay time. In contrast, the ignition delay time was reduced by the higher concentration of $\mathrm{H}_{2}$, indicating that the reactivity of the mixture increased significantly, leading to the faster auto-ignition of the mixture. For laminar flame speed, an identical trend was observed when $\mathrm{CH}_{4}$ and $\mathrm{H}_{2}$ were added. The reactivity of the mixture and hence the laminar flame speed reduced when mixtures with high $\mathrm{CH}_{4}$ content were used, while in contrast the laminar flame speed increased when the amount of $\mathrm{H}_{2}$ in the mixture increased.

For more detailed analysis, methane and hydrogen concentration profiles during the combustion of different $\mathrm{H}_{2} / \mathrm{CH}_{4}$ mixtures, have been calculated at different pressures and different equivalence ratios. The analysis shows that for high-pressure conditions, methane is consumed more gradually, enhancing the reactivity of the mixture more in comparison with low-pressure conditions, in which, methane is consumed rapidly and sharply. Additionally, it was found that at different equivalence ratios, methane is reacting at different temperatures, indicating that at each equivalence ratio, different reactions are triggered affecting the mixture oxidation. Furthermore, it was found that in the presence of hydrogen, methane is consumed more gradually.

Two reaction sensitivity analysis were conducted for the investigation of the important reactions affecting the combustion process. According to the first sensitivity analysis, hydrogen-based and methane-based reactions are found to be the dominant reactions, driving $\mathrm{H}_{2} / \mathrm{CH}_{4} / \mathrm{CO}$ mixture combustion at different equivalence ratios. All of the hydrogen-based reactions identified from the sensitivity analysis were correlated with the formation or the consumption of important $\mathrm{OH}$ radicals indicating that $\mathrm{OH}$ plays a key role in the combustion process. Methane recombination reactions, responsible for the oxidation and consumption of $\mathrm{CH}_{4}$ by metathesis with high reactive $\mathrm{OH}$ radicals, were found to be very important and have high sensitivity factors at all of the equivalence ratios investigated. For the second sensitivity analysis, important reactions affecting the combustion of methane-rich and hydrogen-rich $\mathrm{H}_{2} / \mathrm{CH}_{4}$ mixtures, were analysed. Hydrogen-based reactions such as $\mathrm{H}_{2} \mathrm{O}_{2}+\mathrm{M}=\mathrm{OH}+\mathrm{OH}+\mathrm{M}, \mathrm{H}_{2} \mathrm{O}_{2}+\mathrm{H}=\mathrm{H}_{2}+\mathrm{HO}_{2}, \mathrm{H}+\mathrm{O}_{2}=\mathrm{OH}+\mathrm{O}, \mathrm{H}_{2}+\mathrm{O}=\mathrm{OH}+\mathrm{O}$ and methane-based reactions such as $\mathrm{CH}_{4}+\mathrm{O}_{2}=\mathrm{CH}_{3}+\mathrm{HO}_{2}, \mathrm{CH}_{4}+\mathrm{OH}=\mathrm{CH}_{3}+\mathrm{H}_{2} \mathrm{O}, \mathrm{CH}_{3}+\mathrm{O}_{2}=$ 
$\mathrm{CH}_{2} \mathrm{O}+\mathrm{OH}$ were presented in the sensitivity analyses for both mixtures. However, for methane-rich mixtures, reactions $\mathrm{CH}_{2} \mathrm{O}+\mathrm{OH}=\mathrm{HCO}+\mathrm{H}_{2} \mathrm{O}$ and $\mathrm{CH}_{4}+\mathrm{HO}_{2}=\mathrm{CH}_{3}+\mathrm{H}_{2} \mathrm{O}_{2}$ were found to be more important, while for hydrogen-rich mixtures, reactions $\mathrm{OH}+\mathrm{HO}_{2}=\mathrm{H}_{2} \mathrm{O}+\mathrm{O}_{2}$ and $\mathrm{HO}_{2}+\mathrm{H}=\mathrm{OH}+$ $\mathrm{OH}$ were found to be more important. This is an indicator that by increasing methane concentration and therefore the amount of carbon atoms, the effect of hydrogen is reduced significantly.

Author Contributions: Conceptualization, U.A. and N.S.; methodology, U.A. and N.S.; software, N.S.; validation, N.S. and U.A.; investigation, U.A. and N.S.; resources, U.A.; data curation, N.S.; writing-original draft preparation, N.S. and U.A.; writing-review and editing, M.B.; supervision, U.A. and M.B.

Funding: This research received no external funding.

Acknowledgments: The authors would like to express sincere gratitude to the Researcher Links programme of the British Council for the financial support of this publication.

Conflicts of Interest: The authors declare no conflict of interest.

\section{References}

1. Frassoldati, A.; Faravelli, T.; Ranzi, E.L. A wide range modeling study of NOx formation and nitrogen chemistry in hydrogen combustion. Int. J. Hydrog. Energy 2006, 31, 2310-2328. [CrossRef]

2. Sridhar, G.; Paul, P.J.; Mukunda, H.S. Biomass derived producer gas as a reciprocating engine fuel-An experimental analysis. Biomass Bioenergy 2001, 21, 61-72. [CrossRef]

3. Shilling, N.Z.; Lee, D.T. IGCC-clean power generation alternative for solid fuels. In Proceedings of the PowerGen Asia, Ho Chi Minh City, Vietnam, 23-25 September 2003.

4. Liu, C.C.; Shy, S.S.; Chiu, C.W.; Peng, M.W.; Chung, H.J. Hydrogen/carbon monoxide syngas burning rates measurements in high-pressure quiescent and turbulent environment. Int. J. Hydrog. Energy 2011, 36, 8595-8603. [CrossRef]

5. Brower, M.L.; Mathieu, O.; Petersen, E.L.; Donohoe, N.; Heufer, A.; Metcalfe, W.K.; Curran, H.J.; Bourque, G.; Güthe, F. Ignition Delay Time Experiments for Natural Gas/Hydrogen Blends at Elevated Pressures. In Proceedings of the ASME Turbo Expo 2013: Turbine Technical Conference and Exposition, San Antonio, TX, USA, 3-7 June 2013. GT2013-95151.

6. Tahtouh, T.; Halter, F.; Samson, E.; Mounaïm-Rousselle, C. Effects of hydrogen addition and nitrogen dilution on the laminar flame characteristics of premixed methane-air flames. Int. J. Hydrog. Energy 2009, 34, 8329-8338. [CrossRef]

7. Akansu, S.O.; Dulger, Z.; Kahraman, N.; Veziroğlu, T.N. Internal combustion engines fueled by natural gas-Hydrogen mixtures. Int. J. Hydrog. Energy 2004, 29, 1527-1539. [CrossRef]

8. Ilbas, M.; Crayford, A.P.; Yılmaz, I.; Bowen, P.J.; Syred, N. Laminar-burning velocities of hydrogen-air and hydrogen-methane-air mixtures: An experimental study. Int. J. Hydrog. Energy 2006, 31, 1768-1779. [CrossRef]

9. Mathieu, O.; Kopp, M.; Petersen, E. Shock-tube study of the ignition of multi-component syngas mixtures with and without ammonia impurities. Proceed. Combust. Inst. 2013, 34, 3211-3218. [CrossRef]

10. Watson, G.M.; Munzar, J.D.; Bergthorson, J.M. NO formation in model syngas and biogas blends. Fuel 2014, 124, 113-124. [CrossRef]

11. Tomita, E. Combustion characteristics and performance of supercharged pyrolysis gas engine with micro-pilot ignition. In Proceedings of the 25th CIMAC World Congress on Combustion Engine Technology (CIMAC 2007), Vienna, Austria, 21-24 May 2007; Volume 178, pp. 1-10.

12. Li, H.; Karim, G.A. Exhaust emissions from an SI engine operating on gaseous fuel mixtures containing hydrogen. Int. J. Hydrog. Energy 2005, 30, 1491-1499. [CrossRef]

13. Gersen, S.; Darmeveil, H.; Levinsky, H. The effects of $\mathrm{CO}$ addition on the autoignition of $\mathrm{H}_{2}, \mathrm{CH}_{4}$ and $\mathrm{CH}_{4} / \mathrm{H}_{2}$ fuels at high pressure in an RCM. Combust. Flame 2012, 159, 3472-3475. [CrossRef]

14. Pio, G.; Salzano, E. Laminar burning velocity of methane, hydrogen and their mixtures at extremely low-temperature conditions. Energy Fuels 2018, 32, 8830-8836. [CrossRef]

15. Salzano, E.; Pio, G.; Ricca, A.; Palma, V. The effect of a hydrogen addition to the premixed flame structure of light alkanes. Fuel 2018, 234, 1064-1070. [CrossRef] 
16. Miao, H.; Jiao, Q.; Huang, Z.; Jiang, D. Effect of initial pressure on laminar combustion characteristics of hydrogen enriched natural gas. Int. J. Hydrog. Energy 2008, 33, 3876-3885. [CrossRef]

17. Miao, H.; Jiao, Q.; Huang, Z.; Jiang, D. Measurement of laminar burning velocities and Markstein lengths of diluted hydrogen-enriched natural gas. Int. J. Hydrog. Energy 2009, 34, 507-518. [CrossRef]

18. Valera-Medina, A.; Giles, A.; Pugh, D.; Morris, S.; Pohl, M.; Ortwein, A. Investigation of combustion of emulated biogas in a gas turbine test rig. J. Therm. Sci. 2018, 27, 331-340. [CrossRef]

19. Stylianidis, N.; Azimov, U.; Maheri, A.; Tomita, E.; Kawahara, N. Chemical kinetics and CFD analysis of supercharged micro-pilot ignited dual-fuel engine combustion of syngas. Fuel 2017, 203, 591-606. [CrossRef]

20. Smith, G.P.; Gardiner, W.C.; Lissianski, V.V.; Qin, Z.; Smith, G.P.; Golden, D.M.; Frenklach, M.; Eiteneer, B.; Goldenberg, M.; Moriarty, N.W.; et al. The gri-mechtm model for natural gas combustion and no formation and removal chemistry. In Proceedings of the 5th International Conference on Combustion Technologies for a Clean Environment, Lisbon, Portugal, 12-15 July 1999. Available online: http://www.me.berkeley.edu/gri_mech/ (accessed on 20 November 2018).

21. Azimov, U.; Okuno, M.; Tsuboi, K.; Kawahara, N.; Tomita, E. Multidimensional CFD simulation of syngas combustion in a micro-pilot-ignited dual-fuel engine using a constructed chemical kinetics mechanism. Int. J. Hydrog. Energy 2011, 36, 13793-13807. [CrossRef]

22. Li, S.-C.; Williams, F.A.; Gebert, K. A Reduced Reaction Mechanism for Predicting Knock in Dual-Fuel Engines; SAE Technical Paper; SAE International: Warrendale, PA, USA, 2000.

23. Li, S.; Williams, F. Reaction mechanisms for methane ignition. In Proceedings of the ASME Turbo Expo 2000: Power for Land, Sea and Air, Munich, Germany, 8-11 May 2000; American Society of Mechanical Engineers: New York, NY, USA, 2000.

24. Frassoldati, A.; Faravelli, T.; Ranzi, E. The ignition, combustion and flame structure of carbon monoxide/hydrogen mixtures. Note 1: Detailed kinetic modeling of syngas combustion also in presence of nitrogen compounds. Int. J. Hydrog. Energy 2007, 32, 3471-3485. [CrossRef]

25. Fernández-Galisteo, D.; del Alamo, G.; Sánchez, A.L.; Linán, A. Zeldovich analysis of hydrogen-air premixed flames. In Proceedings of the Third European combustion Meeting, Crete, Greece, 11-13 April 2007.

26. Sutherland, J.; Michael, J.; Pirraglia, A.; Nesbitt, F.; Klemm, R. Rate constant for the reaction of O (3P) with $\mathrm{H}_{2}$ by the flash photolysis-shock tube and flash photolysis-Resonance fluorescence techniques; $504 \mathrm{~K} \leq \mathrm{T} \leq$ 2495K. In Symposium (International) on Combustion; Elsevier: Amsterdam, The Netherlands, 1988.

27. Kéromnès, A.; Metcalfe, W.K.; Heufer, K.A.; Donohoe, N.; Das, A.K.; Sung, C.-J.; Herzler, J.; Naumann, C.; Griebel, P.; Mathieu, O. An experimental and detailed chemical kinetic modeling study of hydrogen and syngas mixture oxidation at elevated pressures. Combust. Flame 2013, 160, 995-1011. [CrossRef]

28. Conaire, M.Ó.; Curran, H.J.; Simmie, J.M.; Pitz, W.J.; Westbrook, C.K. A comprehensive modeling study of hydrogen oxidation. Int. J. Chem. Kinet. 2004, 36, 603-622. [CrossRef]

29. Konnov, A. Remaining uncertainties in the kinetic mechanism of hydrogen combustion. Combust. Flame 2008, 152, 507-528. [CrossRef]

30. CD-Adapco Inc. DARS Basic 2.14; CD-Adapco Inc.: Melville, NY USA, 2019.

31. Das, A.K.; Sung, C.J.; Zhang, Y.; Mittal, G. Ignition delay study of moist hydrogen/oxidizer mixtures using a rapid compression machine. Int. J. Hydrog. Energy 2012, 37, 6901-6911. [CrossRef]

32. Lee, H.C.; Mohamad, A.A.; Jiang, L.-Y. Comprehensive comparison of chemical kinetics mechanisms for syngas/biogas mixtures. Energy Fuels 2015, 29, 6126-6145. [CrossRef]

33. Goodwin, D. Cantera: An Object-Oriented Software Toolkit for Chemical Kinetics, Thermodynamics and Transport Processes; Caltech: Pasadena, CA, USA, 2009.

34. Kathrotia, T.; Fikri, M.; Bozkurt, M.; Hartmann, M.; Riedel, U.; Schulz, C. Study of the H + O + M reaction forming $\mathrm{OH} *$ : Kinetics of $\mathrm{OH} *$ chemiluminescence in hydrogen combustion systems. Combust. Flame 2010, 157, 1261-1273. [CrossRef]

35. CD-Adapco Inc. DARS Manual, Book4: Flames; CD-Adapco Inc.: Melville, NY USA, 2018.

36. CD-Adapco Inc. DARS Manual, Book5: Mechanism Reduction; CD-Adapco Inc.: Melville, NY USA, 2018.

37. Løvås, T. Model reduction techniques for chemical mechanisms. IntechOpen 2012. [CrossRef]

38. Soyhan, H.S.; Amnéus, P.; Løvås, T.; Nilsson, D.; Maigaard, P.; Mauss, F.; Sorusbay, C. Automatic Reduction of Detailed Chemical Reaction Mechanisms for Autoignition Under SI Engine Conditions; SAE Transactions; SAE International: Warrendale, PA, USA, 2000; pp. 1435-1444. 
39. Zhang, Y.; Huang, Z.; Wei, L.; Zhang, J.; Law, C.K. Experimental and modeling study on ignition delays of lean mixtures of methane, hydrogen, oxygen and argon at elevated pressures. Combust. Flame 2012, 159, 918-931. [CrossRef]

40. Donohoe, N.; Heufer, A.; Metcalfe, W.K.; Curran, H.J.; Davis, M.L.; Mathieu, O.; Plichta, D.; Morones, A.; Petersen, E.L.; Güthe, F. Ignition delay times, laminar flame speeds and mechanism validation for natural gas/hydrogen blends at elevated pressures. Combust. Flame 2014, 161, 1432-1443. [CrossRef]

41. Hermanns, R.T.E. Laminar Burning Velocities of Methanehydrogen-Air Mixtures. Ph.D. Thesis, Technische Universiteit Eindhoven, Eindhoven, The Netherlands, 2007.

42. Coppens, F.H.V.; De Ruyck, J.; Konnov, A.A. The effects of composition on burning velocity and nitric oxide formation in laminar premixed flames of $\mathrm{CH}_{4}+\mathrm{H}_{2}+\mathrm{O}_{2}+\mathrm{N}_{2}$. Combust. Flame 2007, 149, 409-417. [CrossRef]

43. Lapalme, D.; Seers, P. Influence of $\mathrm{CO}_{2}, \mathrm{CH}_{4}$ and initial temperature on $\mathrm{H}_{2} / \mathrm{CO}$ laminar flame speed. Int. J. Hydrog. Energy 2014, 39, 3477-3486. [CrossRef]

44. Cong, T.L.; Dagaut, P. Experimental and detailed kinetic modeling of the oxidation of methane and methane/syngas mixtures and effect of carbon dioxide addition. Combust. Sci. Technol. 2008, 180, $2046-2091$. [CrossRef]

45. Dufour, A.; Valin, S.; Castelli, P.; Thiery, S.; Boissonnet, G.; Zoulalian, A.; Glaude, P.A. Mechanisms and kinetics of methane thermal conversion in a syngas. Ind. Eng. Chem. Res. 2009, 48, 6564-6572. [CrossRef]

46. Liu, J.; Zhang, X.; Wang, T.; Hou, X.; Zhang, J.; Zheng, S. Numerical study of the chemical, thermal and diffusion effects of $\mathrm{H}_{2}$ and $\mathrm{CO}$ addition on the laminar flame speeds of methane-air mixture. Int. J. Hydrog. Energy 2015, 40, 8475-8483. [CrossRef]

47. Roy, M.M.; Tomita, E.; Kawahara, N.; Harada, Y.; Sakane, A. Performance and emission comparison of a supercharged dual-fuel engine fueled by producer gases with varying hydrogen content. Int. J. Hydrog. Energy 2009, 34, 7811-7822. [CrossRef]

48. Li, M.; Zhang, Q.; Li, G.; Li, P. Effects of hydrogen addition on the performance of a pilot-ignition direct-injection natural gas engine: A numerical study. Energy Fuels 2017, 31, 4407-4423. [CrossRef]

49. Hong, Z.; Davidson, D.F.; Hanson, R.K. An improved $\mathrm{H}_{2} / \mathrm{O}_{2}$ mechanism based on recent shock tube/laser absorption measurements. Combust. Flame 2011, 158, 633-644. [CrossRef]

50. Westbrook, C.K. Chemical kinetics of hydrocarbon ignition in practical combustion systems. Proc. Combust. Inst. 2000, 28, 1563-1577. [CrossRef]

51. Kappel, C.; Luther, K.; Troe, J. Shock wave study of the unimolecular dissociation of $\mathrm{H}_{2} \mathrm{O}_{2}$ in its falloff range and of its secondary reactions. Phys. Chem. Chem. Phys. 2002, 4, 4392-4398. [CrossRef]

52. Baulch, D.L.; Cobos, C.J.; Cox, R.A.; Frank, P.; Hayman, G.; Just, T.; Kerr, J.A.; Murrells, T.; Pilling, M.J.; Troe, J.; et al. Summary table of evaluated kinetic data for combustion modeling: Supplement 1. Combust. Flame 1994, 98, 59-79. [CrossRef]

53. Natarajan, K.; Roth, P. High temperature rate coefficient for the reaction of $\mathrm{O}(3 \mathrm{P})$ with $\mathrm{H}_{2}$ obtained by the resonance absorption of $\mathrm{O}$ and $\mathrm{H}$ atoms. Combust. Flame 1987, 70, 267-279. [CrossRef]

54. Javoy, S.; Naudet, V.; Abid, S.; Paillard, C.E. Rate constant for the reaction of $\mathrm{O}$ with $\mathrm{H}_{2}$ at high temperature by resonance absorption measurements of $\mathrm{O}$ atoms. Int. J. Chem. Kinet. 2000, 32, 686-695. [CrossRef]

55. Nikolaou, Z.M.; Chen, J.Y.; Swaminathan, N. A 5-step reduced mechanism for combustion of $\mathrm{CO} / \mathrm{H}_{2} / \mathrm{H}_{2} \mathrm{O} / \mathrm{CH}_{4} / \mathrm{CO}_{2}$ mixtures with low hydrogen/methane and high $\mathrm{H}_{2} \mathrm{O}$ content. Combust. Flame 2013, 160, 56-75. [CrossRef]

56. Hashemi, H.; Christensen, J.M.; Gersen, S.; Levinsky, H.; Klippenstein, S.J.; Glarborg, P. High-pressure oxidation of methane. Combust. Flame 2016, 172, 349-364. [CrossRef]

57. Giménez-López, J.; Millera, A.; Bilbao, R.; Alzueta, M.U. Experimental and kinetic modeling study of the oxy-fuel oxidation of natural gas, $\mathrm{CH}_{4}$ and $\mathrm{C}_{2} \mathrm{H}_{6}$. Fuel 2015, 160, 404-412. [CrossRef]

58. Aul, C.J.; Metcalfe, W.K.; Burke, S.M.; Curran, H.J.; Petersen, E.L. Ignition and kinetic modeling of methane and ethane fuel blends with oxygen: A design of experiments approach. Combust. Flame 2013, 160, 1153-1167. [CrossRef]

59. Srinivasan, N.K.; Su, M.C.; Sutherland, J.W.; Michael, J.V. Reflected shock tube studies of high-temperature rate constants for $\mathrm{CH}_{3}+\mathrm{O}_{2}, \mathrm{H}_{2} \mathrm{CO}+\mathrm{O}_{2}$ and $\mathrm{OH}+\mathrm{O}_{2}$. J. Phys. Chem. A 2005, 109, 7902-7914. [CrossRef] 
60. Burke, M.P.; Chaos, M.; Ju, Y.; Dryer, F.L.; Klippenstein, S.J. Comprehensive $\mathrm{H}_{2} / \mathrm{O}_{2}$ kinetic model for high-pressure combustion. Int. J. Chem. Kinet. 2012, 44, 444-474. [CrossRef]

61. Chemical-Kinetic Mechanisms for Combustion Applications. Mechanical and Aerospace Engineering (Combustion Research), University of California at San Diego, 2011. Available online: http://combustion. ucsd.edu (accessed on 20 November 2018).

(c)

(C) 2019 by the authors. Licensee MDPI, Basel, Switzerland. This article is an open access article distributed under the terms and conditions of the Creative Commons Attribution (CC BY) license (http://creativecommons.org/licenses/by/4.0/). 